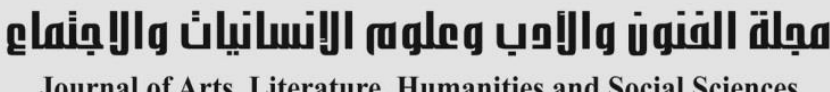

www.jalhss.com

\title{
الوسطية في الإسلام
}

\author{
الاكتورة شيدا زياد درويش طاهر

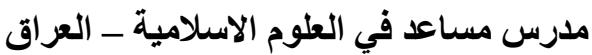 \\ البريد الاكتروني: Shaidazeyad89@gmail.com
}

الملخص

الوسطية في الإسلام هي الاعتدال في أمور الحياة من تصورات ومناهج، ومن أبرز خصائص ومزايا الإسلام، وهي وسام شرف الأمة، وبهذا استحقت الامة ان تكون شاهدة على الناس، قال تعالى: (وَكَذَللِكَ جَعَنْكَكُمْ

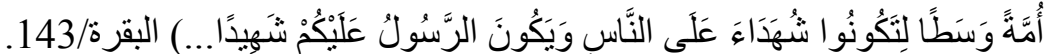
قال الإمام الطبري - رحمه الله-: "و أرى أن اله تعالى ذِكُره إنما وصفهم بأنهم "وسَط": لتوسطهم في الدين، فلا

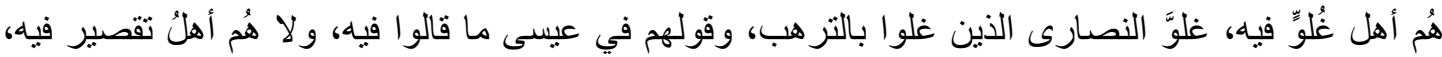

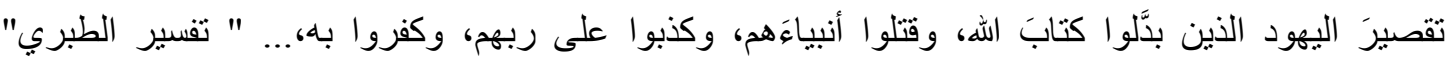

وقال ابن القيم ــرحمه الله-: "فين الله بين الغالي فيه، و الجافي عنهه... إغاثة اللهفان: 182/1. وكذلك الوسطية تعني منهج فكري وموقف أخلافي وسلوكي، كما ذكر في القرآن: (وَابنتَغ فِيمَا آتَاكَكَ اللَّهُ الدَّارَ

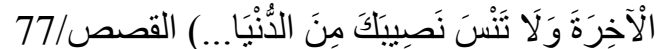
وتمكن أهمية الدراسة في كونها تعالج ظاهرة الانحر افات الفكرية والسلوكية والبعد عن منهج الوسطية، التي

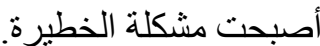




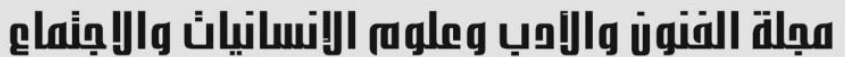

Journal of Arts, Literature, Humanities and Social Sciences

www.jalhss.com

\section{Moderation in Islam}

\author{
Dr. Shaida Zeyad DarweshTaher \\ Assistant Lecturer in Islamic Sciences - Iraq \\ Email: shaidazeyad89@gmail.com
}

\begin{abstract}
Centrality in Islam is the moderation in matters of life of perceptions and methods, and the most prominent characteristics and advantages of Islam, which is the honor of the nation, and thus deserved to be a witness to the people, Allah says: (And so we have made you a median nation, in order that you will be a witness above the people, and that the Messenger be a witness above you...) [Al Baqarah. 143].

Imam al-Tabari (may Allah have mercy on him) said: "And I see that Allah has described them as a" middle nation ": for their centrality in religion, they are not the people of excess, and They are not the people of ignoring, the ignoramus of the excesses of the Christians, Saying in Jesus what they said, of the Jews who changed the book of God, and killed their prophets, and lied about their Lord, and disbelieved him,. . . "Tafseer al-Tabari" (3/142).

Ibn al-Qayyim (may Allah have mercy on him) said: "The religion of Allah is between excess in it and such, the ighorance of it Ighthat al-Lahfan: 1/182.

As such, moderation is an intellectual approach and moral and behavioral position, as mentioned in the Qur'an: (But seek, in that which Allah has given you to attain the Everlasting residence. Do not forget your share in this world...) [Al-Qasas. 77].

The importance of the study in dealing with the phenomenon of intellectual and behavioral deviations and distance from the method of moderation, which become a serious problem.
\end{abstract}

Keywords: Moderation, Islam, Happiness, Moderation. 


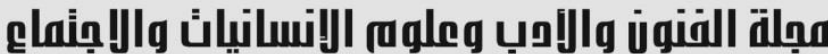

Journal of Arts, Literature, Humanities and Social Sciences

www.jalhss.com

الحمد لله و الصلاة والسلام على محمد وآله وصحبه، فان الاسلام تميز بالوسطية والاعتدال و السماحة واليسر

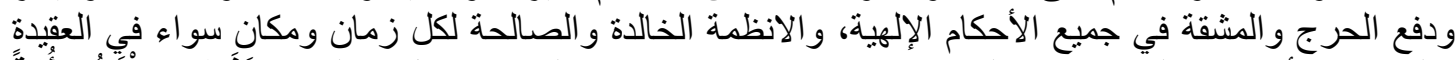

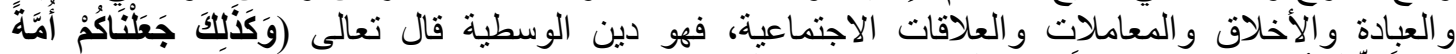

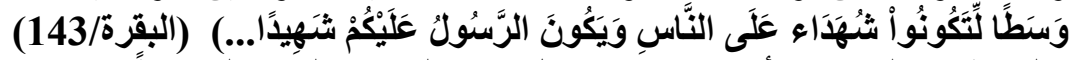

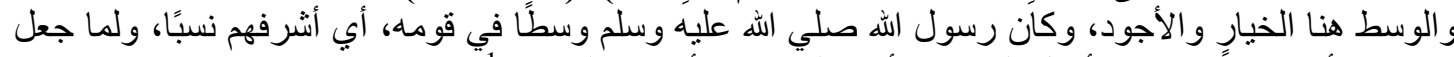

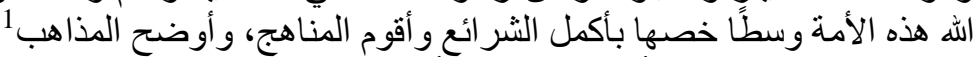

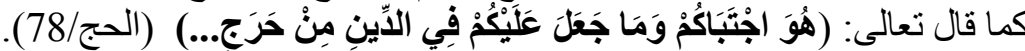

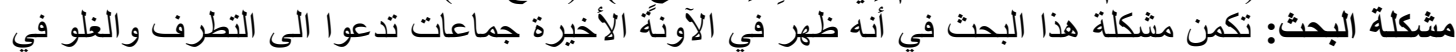

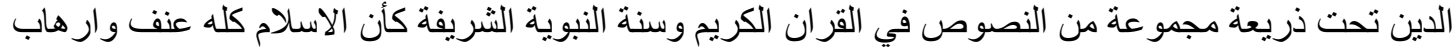

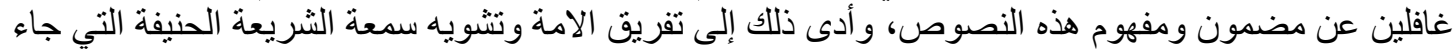

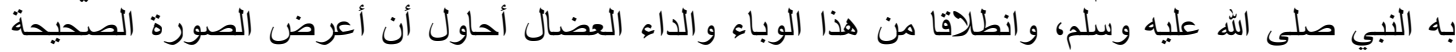

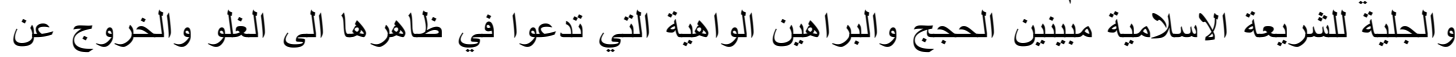
المنهج الوسطية.

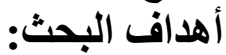

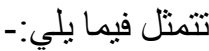
1-بيان مفهوم الوسطية في الاسلام. 2-بيان أثر الانحر اف عن مفهوم الوسطية في الإسلام.

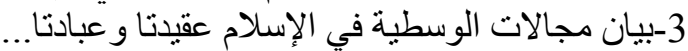

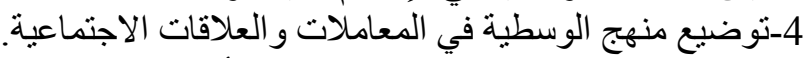

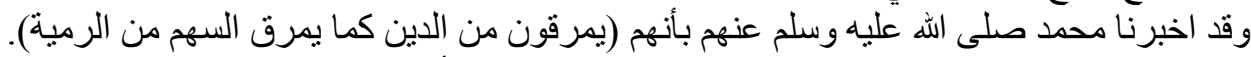

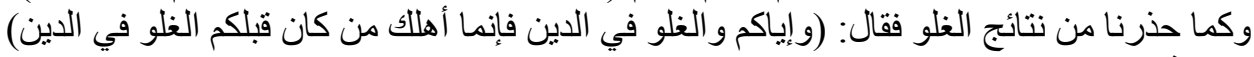

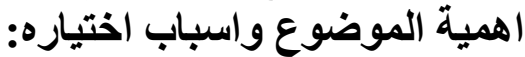

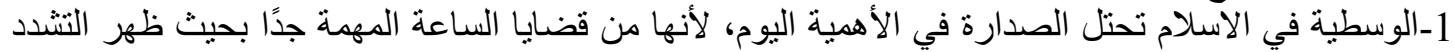

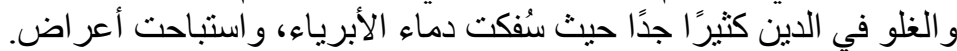

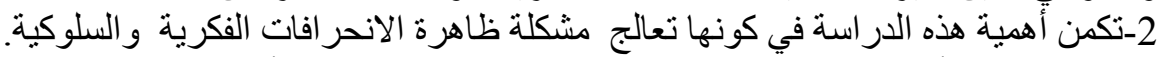
3- الوسطية من أبرز خصائص الأفي ومز ايا الإسلام، وهي وسام شرف الأمة الإنة الإسلامية.

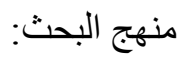

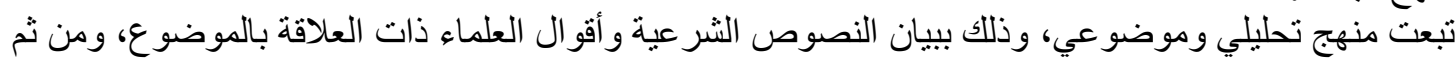

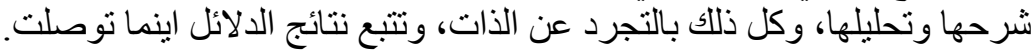
وتتكون الخطة من ستة محاور التالية: المحور الاول: معانى الوسطية، ودليلها، ومنهانة ومهومهها: تتضمن معنى الوسطية في اللغة، وفي القران الكريم ووجوه استعماله، وبيانها في السنة النبوية التهاية

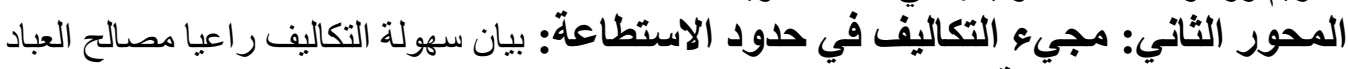

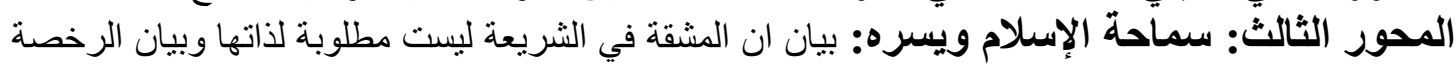

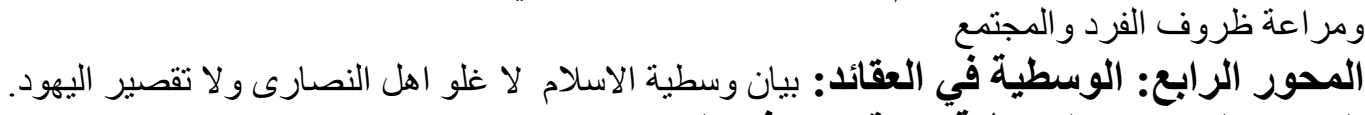

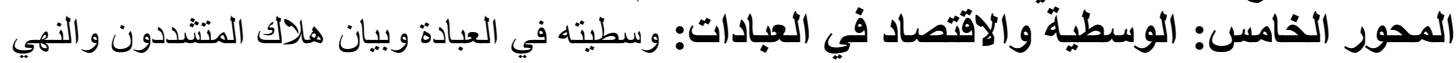
عنها والامتلة عليها. المحور السادل: الوسطية في المعاملات ومكارم الاخلاق: منهية القرآن فيها، والحذر من الاسر اف الخاتمة 1 1- النتائج 2- التوصيات. المصادر والمراجع. 


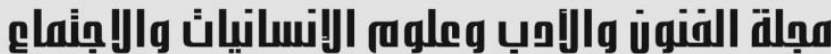

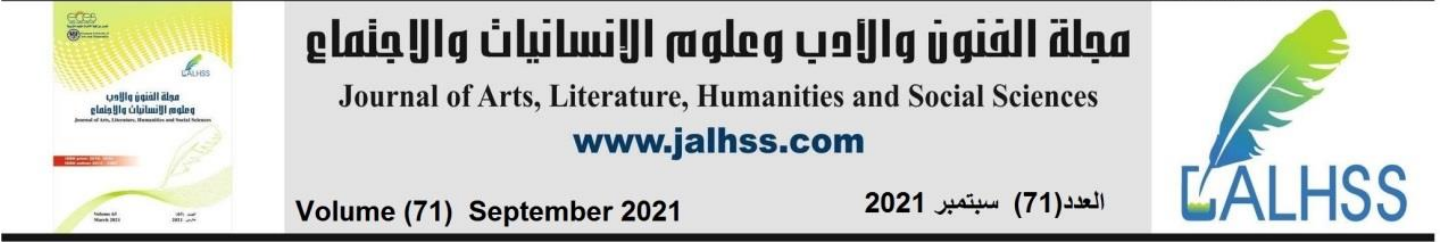

المحور الأول: معاني الوسطية ودليلها، ومفهومها

معني الوسطية في اللغة العربية2

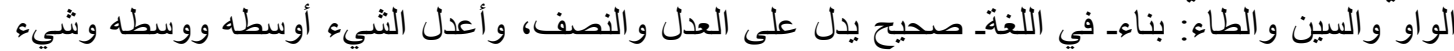

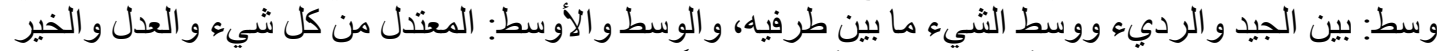
وفلان وسيط في قومه: إذا كان أوسطهم نسبًا وأرفعهم محلاً

\section{ولم تك نسبتي في آل عمرو}

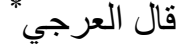

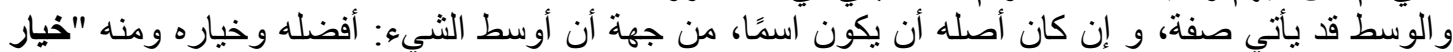

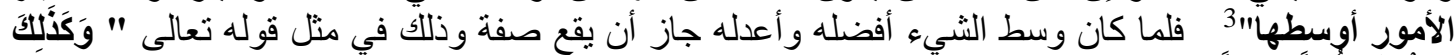

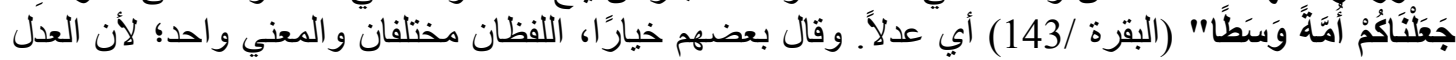

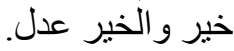

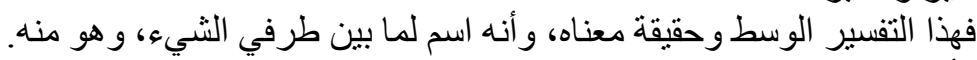
وأما " الوسط " بسكون السين فهو ظرف لا اسم، جاء على وزئن نظيره في المعني و هو "بين" تقول: جلست

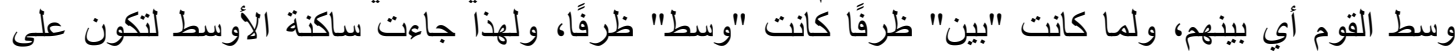

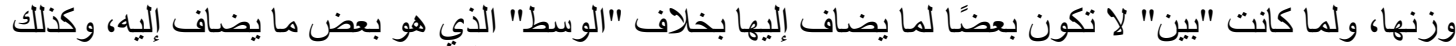

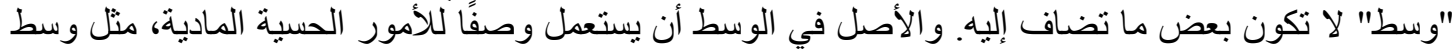

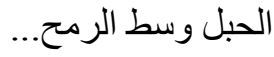

\section{مغنى الوسطيَة في القرآن الكريم}

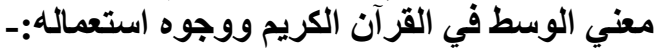

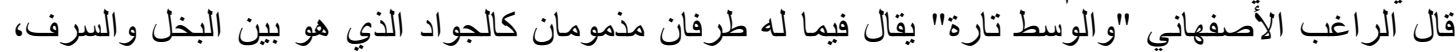

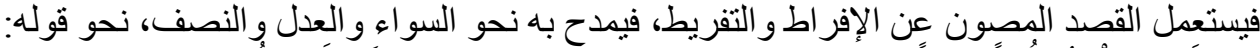

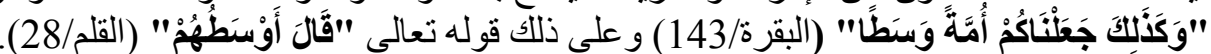

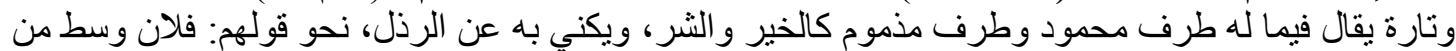

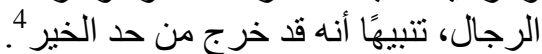

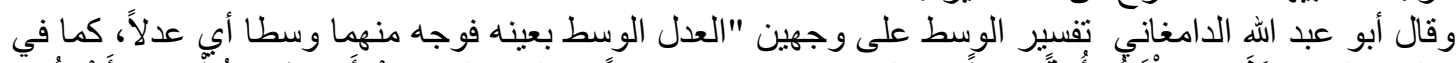

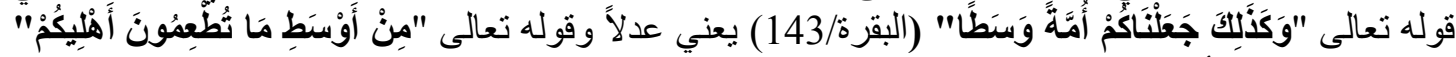

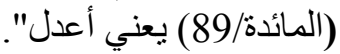

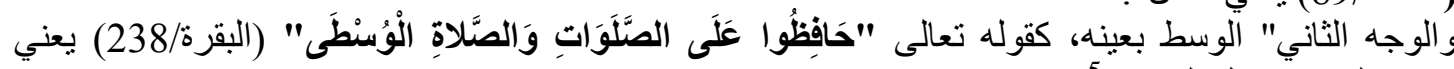
صلاة العصر وقيل الصبح" الصبئه

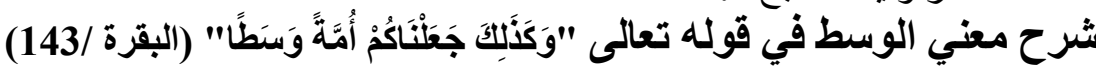

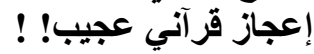
"من إعجاز "القرآن الكريم الدبهر إذا تألمانا هذه الآية الكريمة نجدها تقع في وسط سورة البقرة تمائا ورقمها

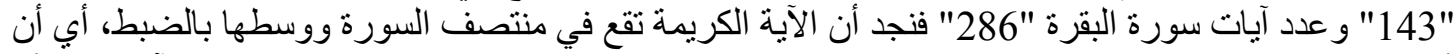

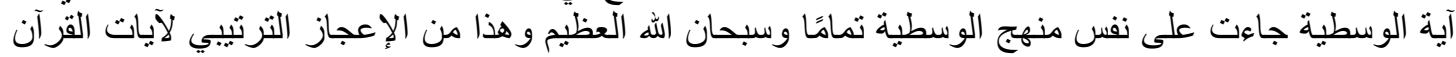

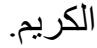
جاء معنى الوسط في الآية الكريمة على أربعة معان كلها متقاربة تمائًا. المغنى الأول: الوسط وهو الأل العدل.

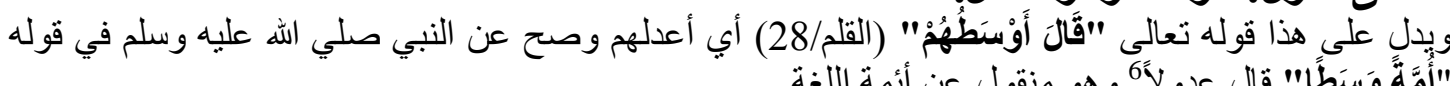

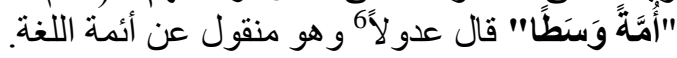




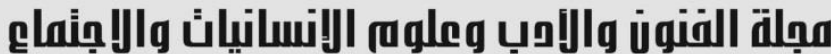

\begin{tabular}{|c|c|c|c|}
\hline 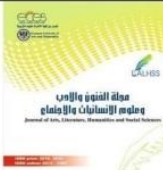 & 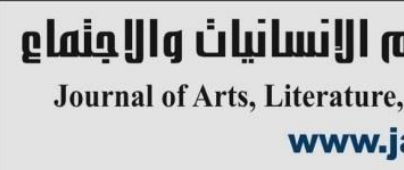 & 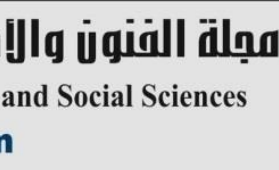 & \\
\hline$==$ & Volume (71) September 2021 & العدد(71) سبتمبر 2021 & \\
\hline
\end{tabular}

قال البقاعي 7 "مادة الوسط" بتصاريفها تدل على العدل السواء الذبي نسبته إلى كل الجو انب التساوي...

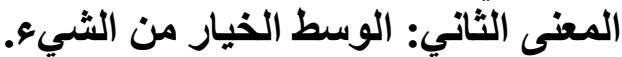
قال أبو حيان الجياني المفسر 8 "ت سنة

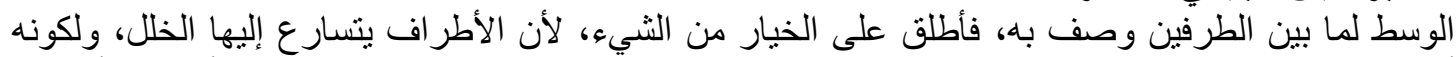

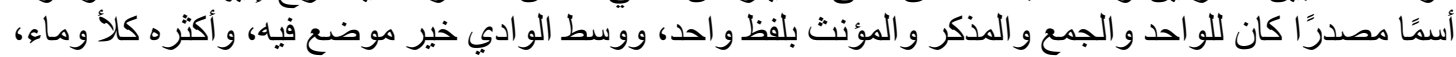

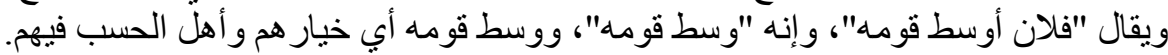

المعنى الثالث: الوسط الأكثر فضلاً. فإذا قيل فلان أوسطنا نسبًا، فالمعني أنه أكثر فضلاً، و وذا وسط فئر فيهم كو اسطة القلادة.

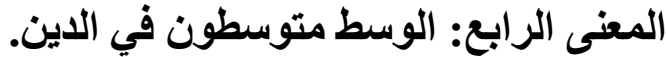

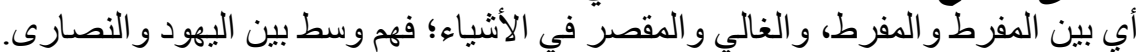

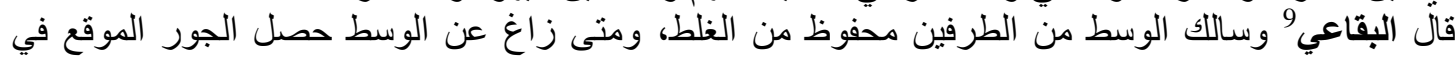

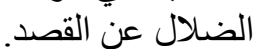

\section{معنى الوسطية في السنة النبوية.} النبي صلي الله عليه وسلم فسر الوسطية في السنة بالعدل قال صلي الله عليه وسلم "يجيء نو حو و أمتها، فيقول الله

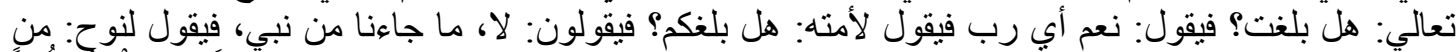

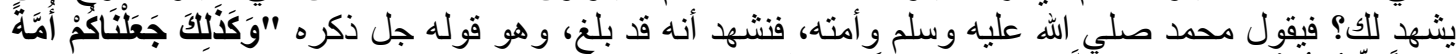

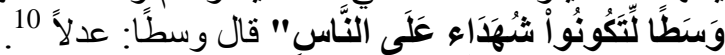

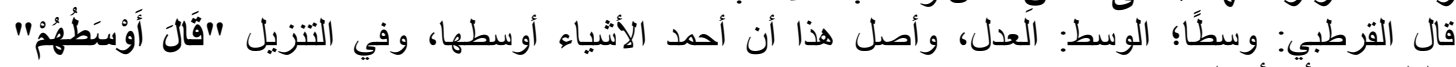
(القلم/28) أي أعدلهم وخير هم الرنط

قال عمر بن الخطاب رضي الله عنه" "أوشك الله أن يقبض هذا العلم قبطًا سريعًا فمن كان عنده منه شيء

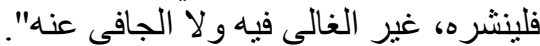

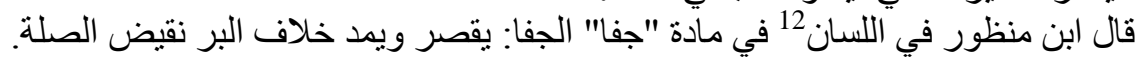

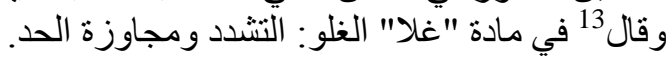

النهي عن الظلو في الدين ومجاوزة الحد. وفي ألحديث" "إن من إجلال اله إكرام ذي الثيبة المسلم، والسلطان المقسط، وحامل القرآن غير الغالي فيه

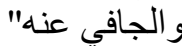
قال ابن منظور 15 وقوله "وحامل القرآن غير الغالي فيه ولا الجافي عنه إنما قال ذلك لأن من آدابه و أخلاقه التي

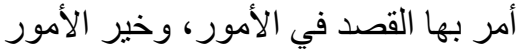

المحور الثاني: مجيء التكاليف في حدود الاسنطاعة لئني

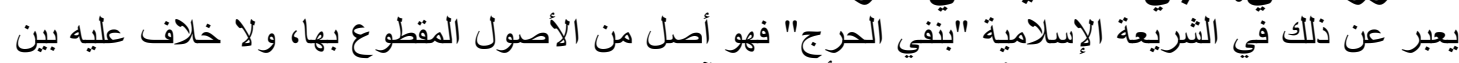
دلماء الثريعة، ويدل عليه في القرآن الكريم ما يأتي من الآيات:

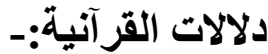

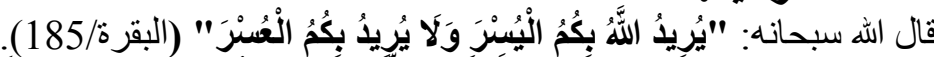

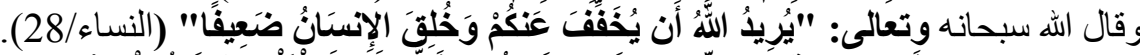

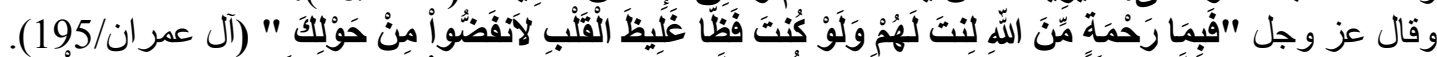

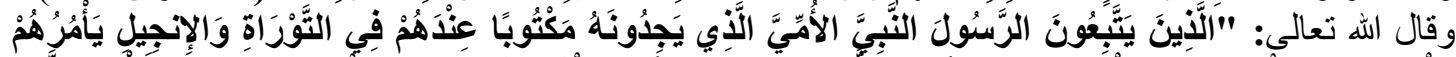

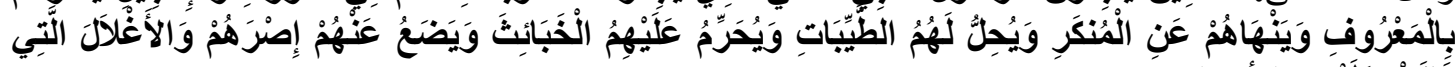

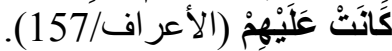




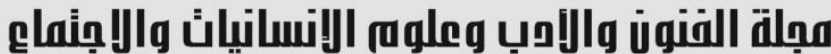

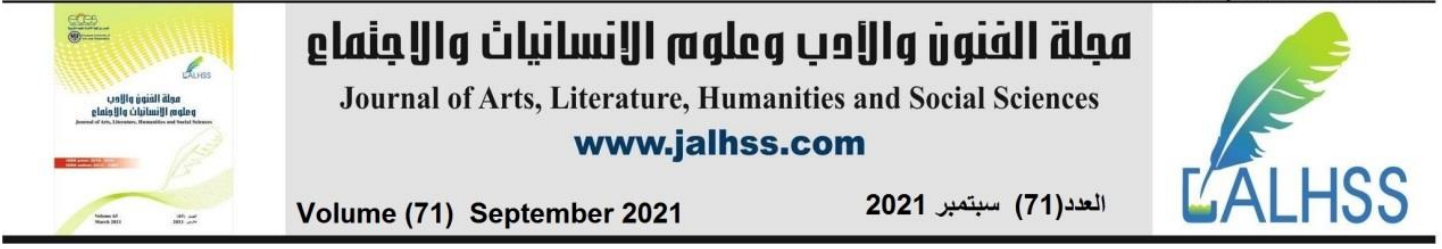

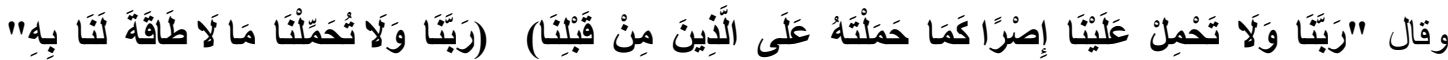

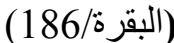

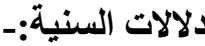
وقد سري هذا المبدأ من الكتاب إلى السنة المطهرة: فقد روي جابر عن النبي صلي الله عليه وسلم أنه قال "بعثت

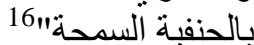
من شمائل النبي صلي الله عليه وسلم اختيار الأيسر:

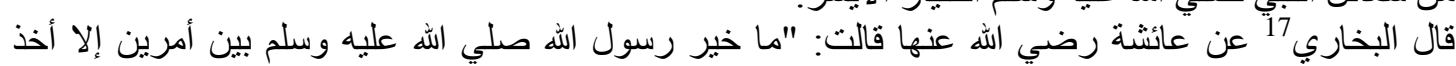

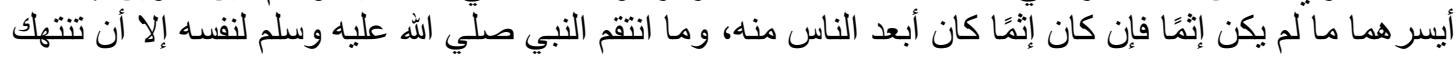

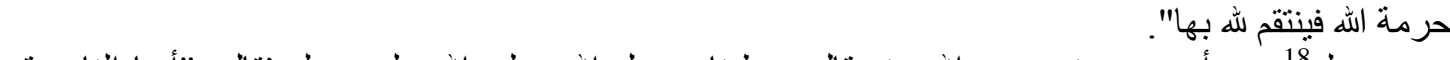

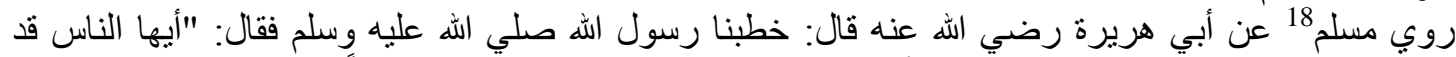

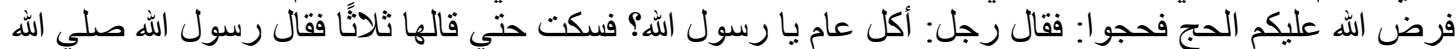

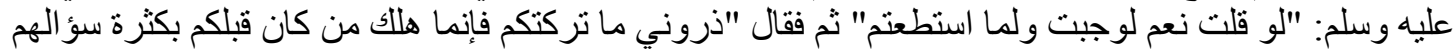

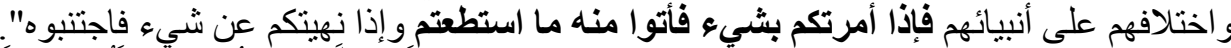

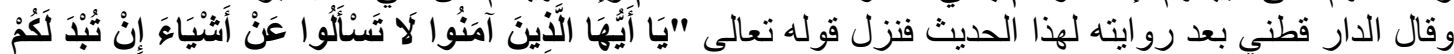

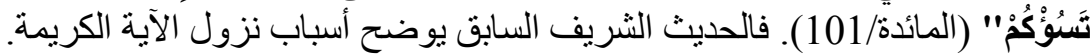

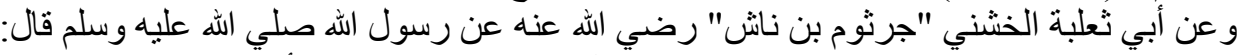

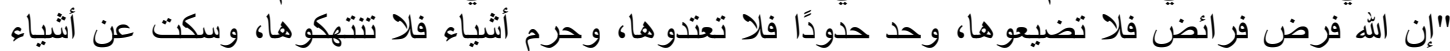

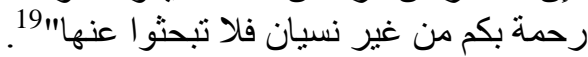
الشريعة ومصالح العباد قال ابن القيم: 20 "...فإن الثريعة الثبال مبناها وأساسها على الحكم ومصالح العباد في المعاش و المعاد، وهي عدل

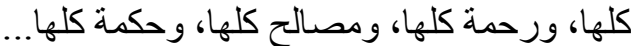
وفي الحديث: " عليكم من الأعمال بما تطيقون، فإنهان اله لا بمل حتى تملو ا"21

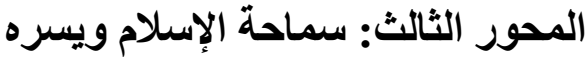

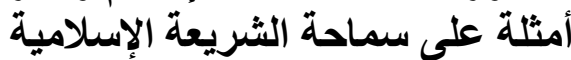

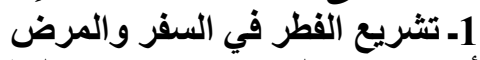

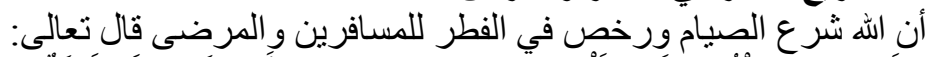

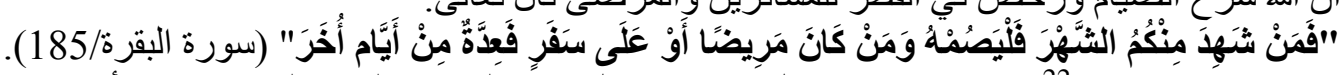

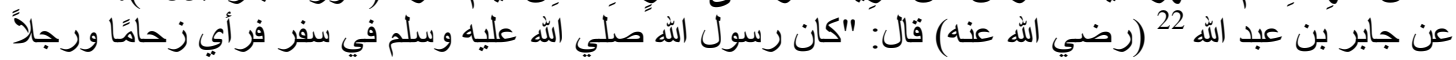

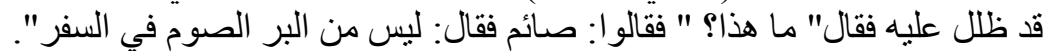

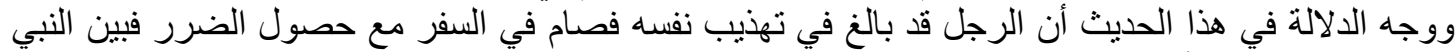

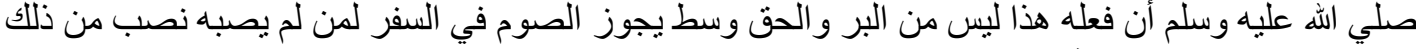
2- تشريع التيمم عند فقد الماءه. 3- تثريع التمتع بالأزواج كل على فلى قدره.

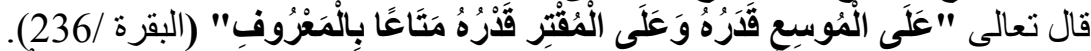

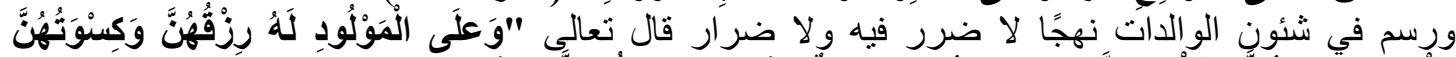

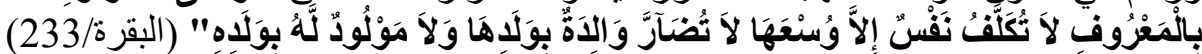

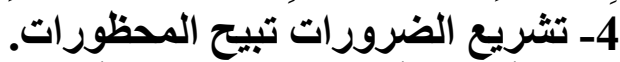

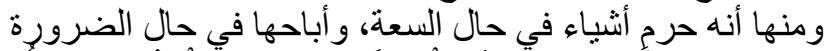

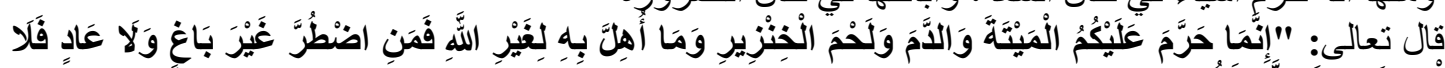

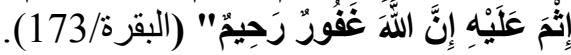




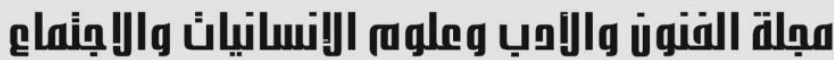

Journal of Arts, Literature, Humanities and Social Sciences

www.jalhss.com

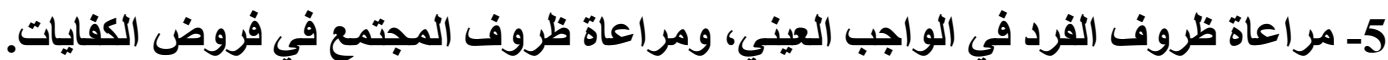

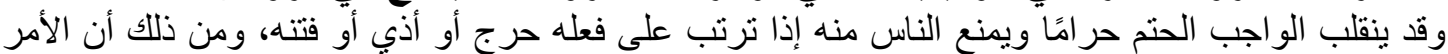

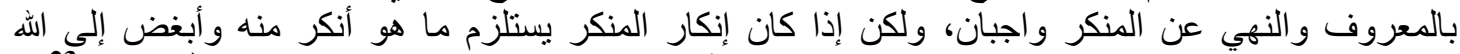

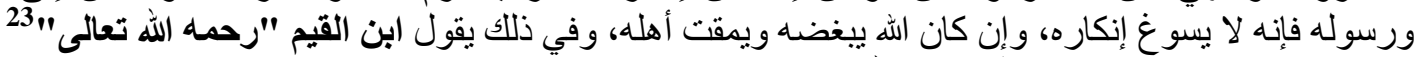
"وسمعت شيخ الإسلام ابن تيمية رحمه الله يقول: مررت أنا وبعض أصحابي في زمن التنار بقوم منهم يشربون الخمر فأنكر عليهم من كان معي فأنكرت

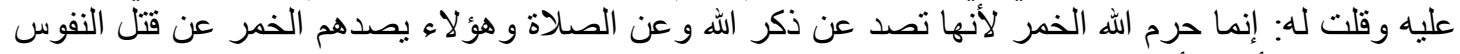

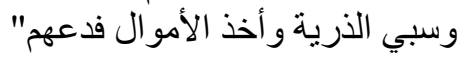

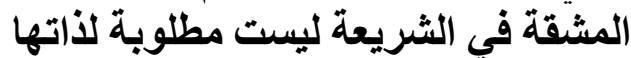

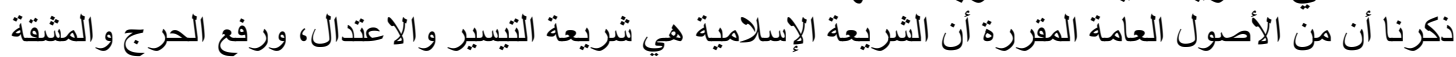

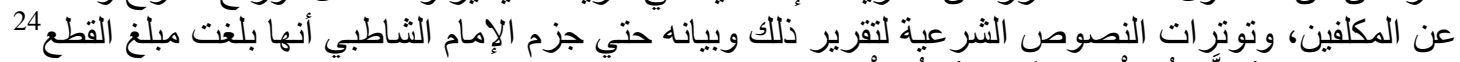

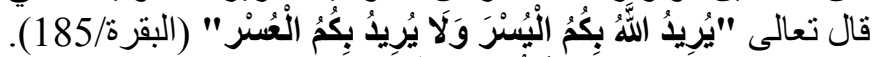

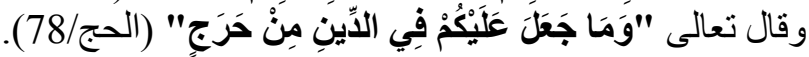

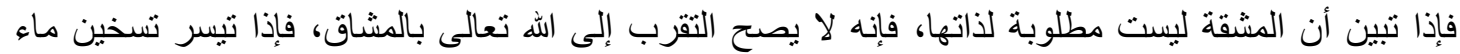

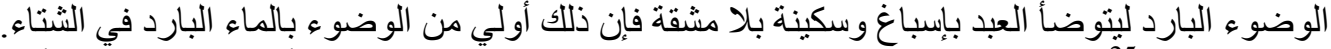

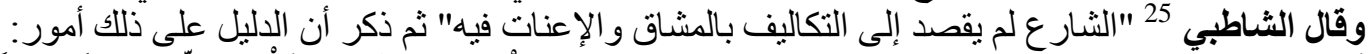

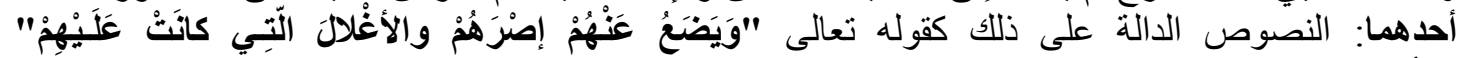

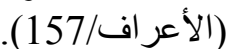

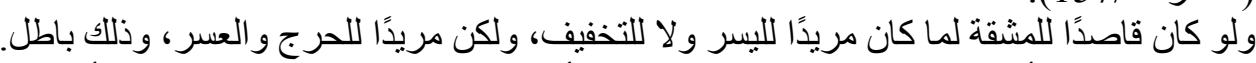

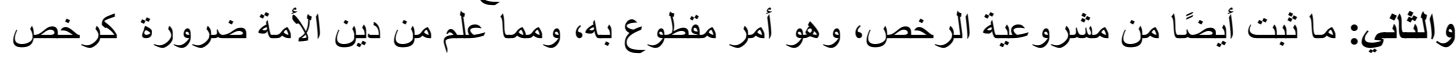

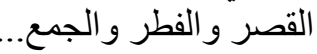
ولو كان الثار ع قاصدًا للمشقة في التكاليف لما كان تم ترخيص و ولا تخفيف.

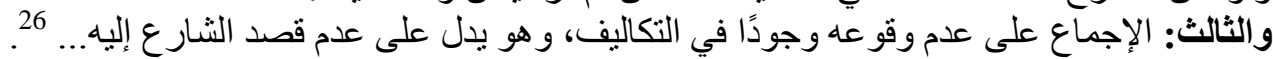
ومن هذا يتبين معني قولهم "المشقة تجلب التيسير" و "الضرورات التهات تبيح المحظورات".

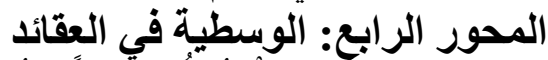

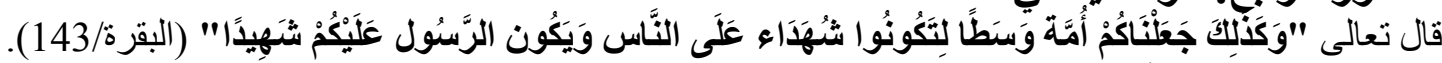

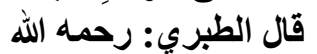

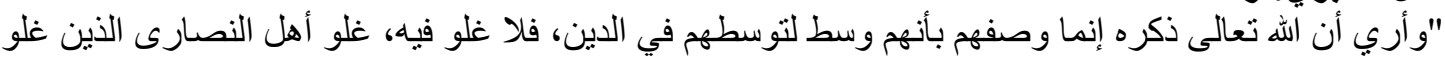

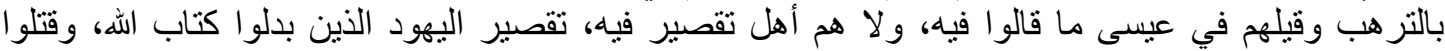

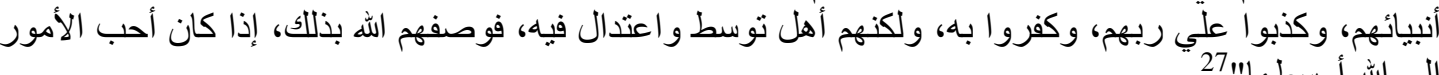

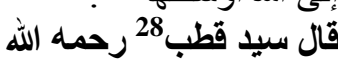
"وكذلك هذه الأمة أمة وسط في التصور والهُ والاعتقاد... امةً وسطًا في التفكير والثعور، لا تجمد على ما علمت وتغلق منافذ التجربة و المعرفة، و ولا نتبع ـ كذلك ـ كل ناعق...

قال ابن تيمية

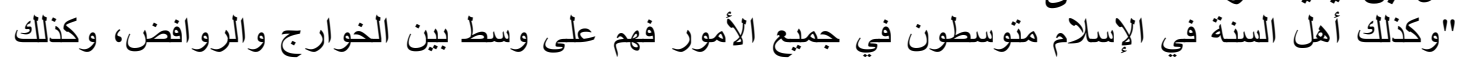

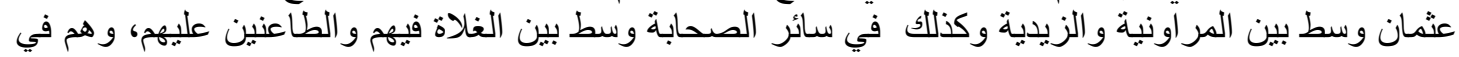

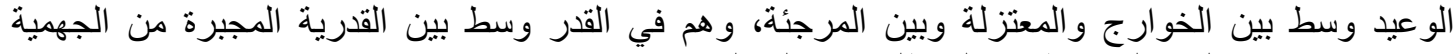

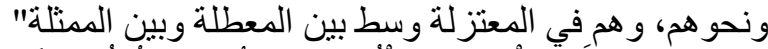

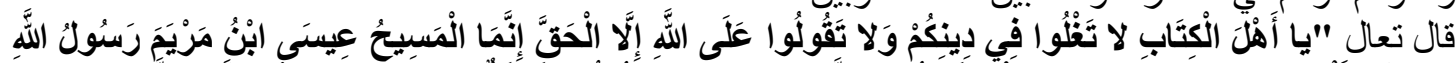

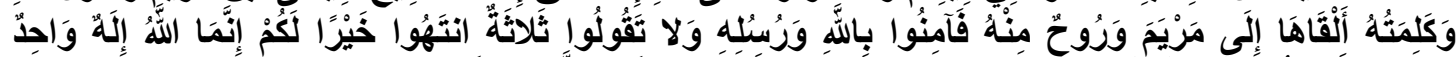

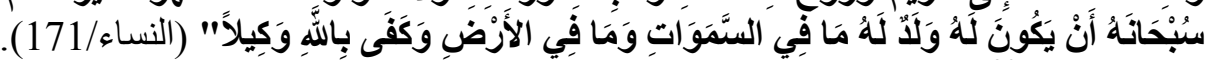

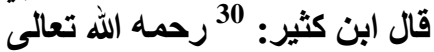




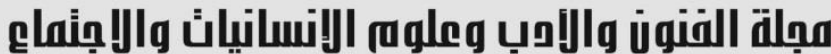

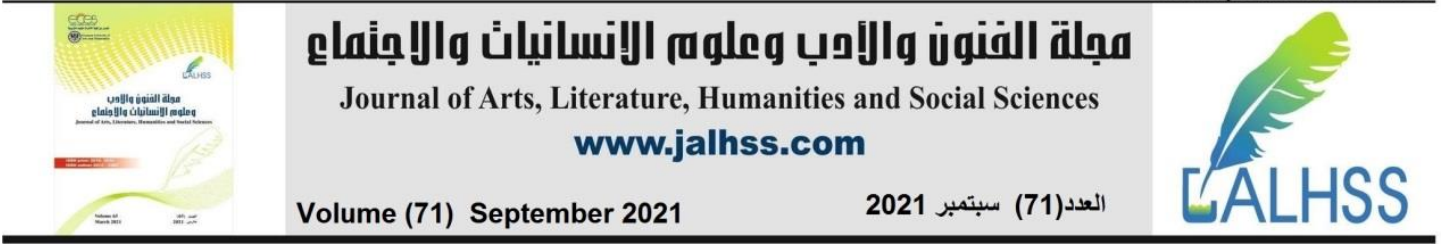

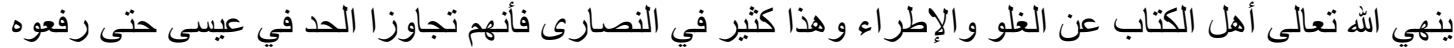

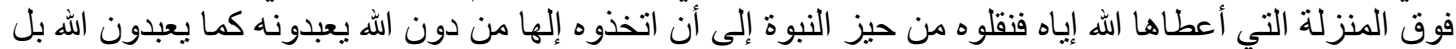

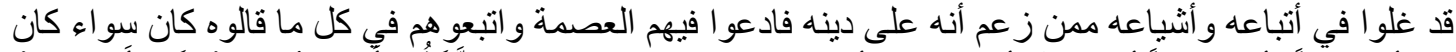

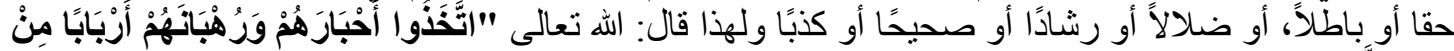

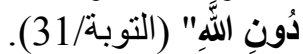

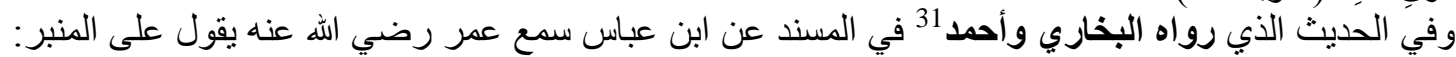

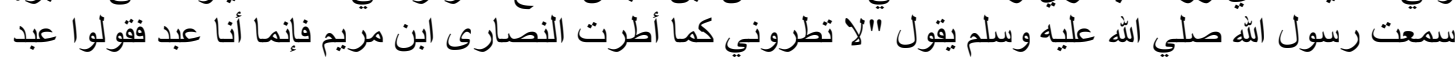

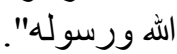

\section{المحور الخامس الوسطية والاقتصاد في العبادات}

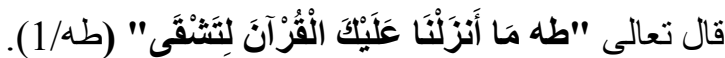

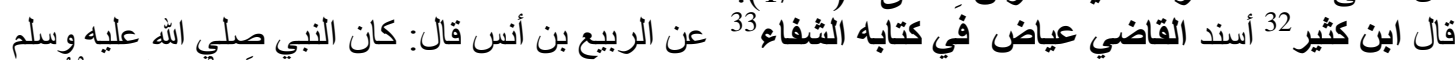

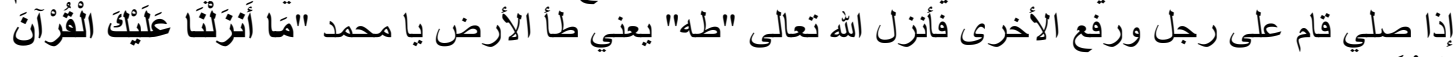

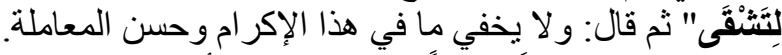

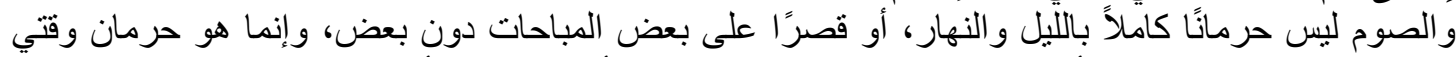

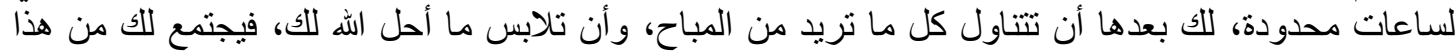
وذالك تربية الروح وتلبية الجسم.

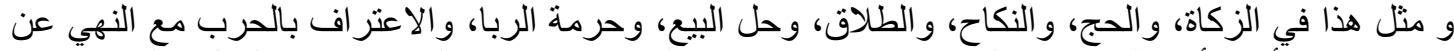

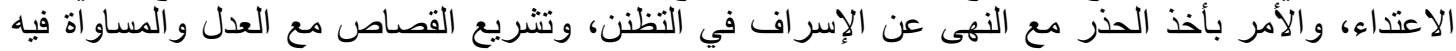

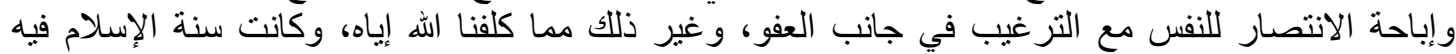

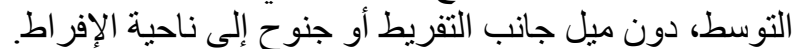

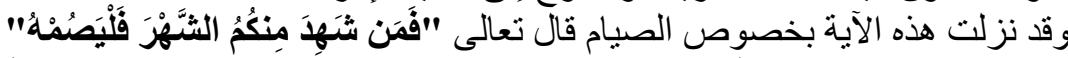

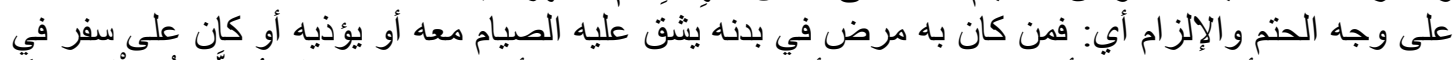

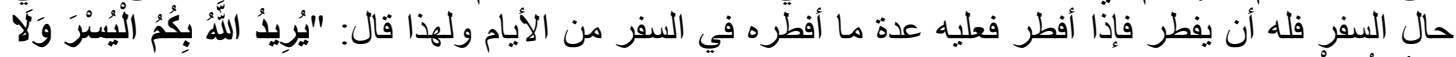

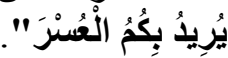

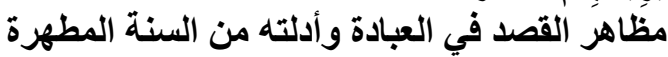

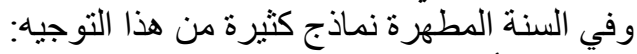

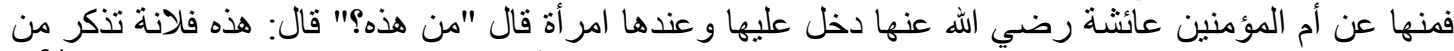

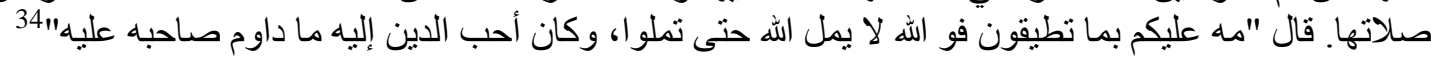

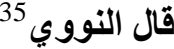

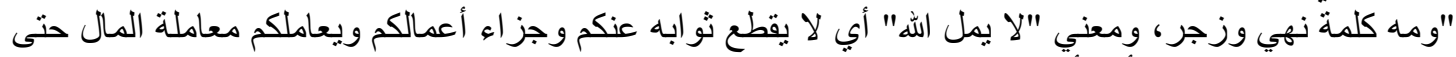

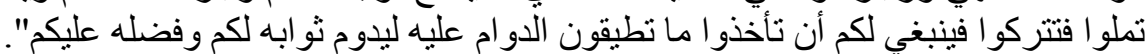

بيان هلاك المتثددون وفي الحديث الذي رواه مسلم36 و غيره عن الأحنف بن قيس عن عبد الله بن مسعود فال: قال رسول الله صلى الله

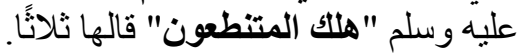

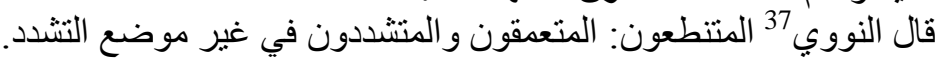
وقد فصل الدكتور يوسف القرضاوي بعض مظاهر التُبن التطرف، منها: 1. التعصب للر أي و عدم الاعتر الف باف بالر أي الأخر.

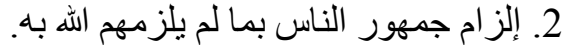

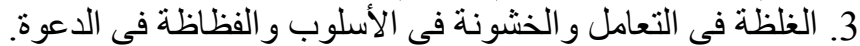
4. السقوط في هاوية التكفير 38 


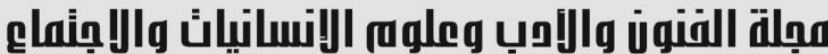

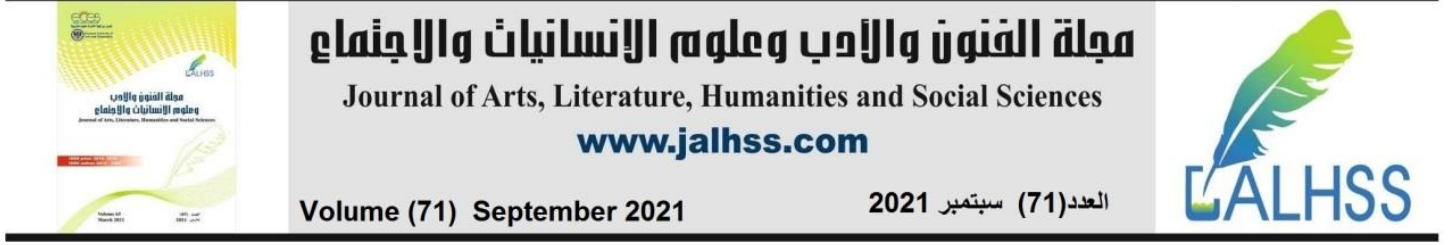

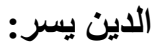

قال البخاري عن أبي هريرة رضي الهه عنه عن النبي صلي الله عليه وسلم قال "إن الدين يسر ولن يشاد الدين احد

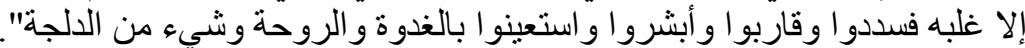

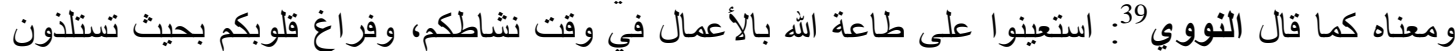

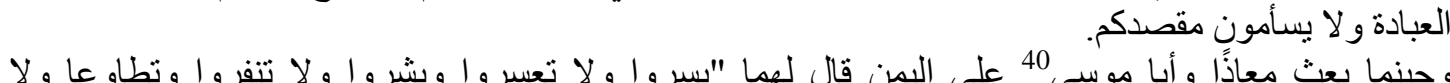
تختلفا" وحينما بعا

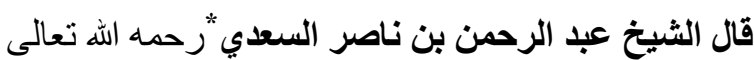

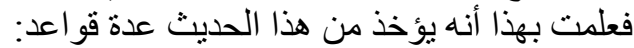

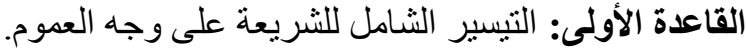

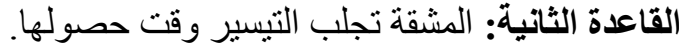

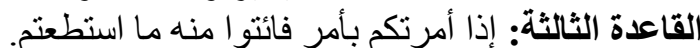

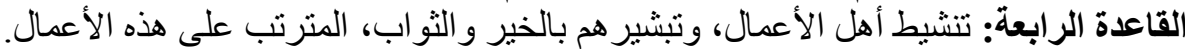

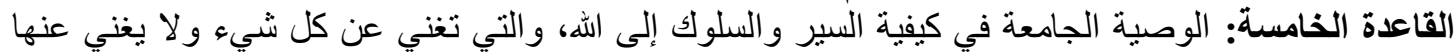

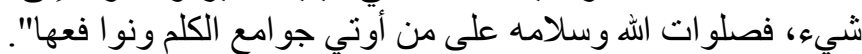

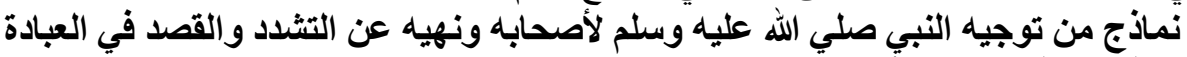
رواية القصة في مسند أُحمد

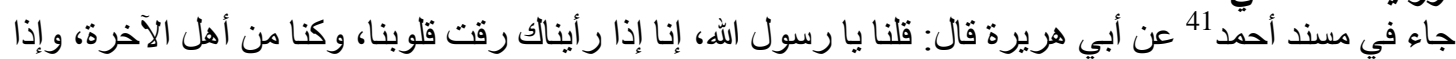

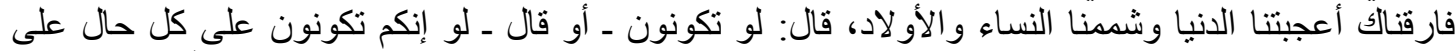

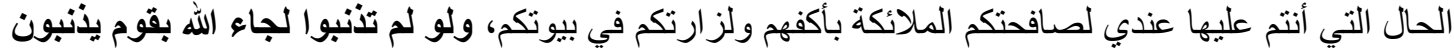

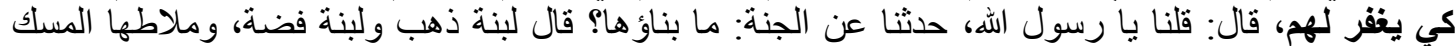

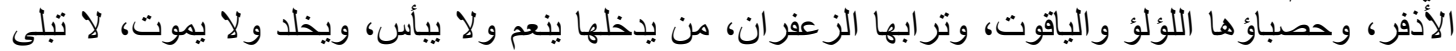

\section{قصة زينب رضي الله عنها "أم المؤمنين"}

روى البخاري ومسلم 42 عن أنس قال: دخل رضين" رسول الله صلي الله عليه وسلم المسجد وحبلُ ممدود بين ساريتين*

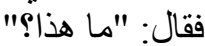

قالو ا: لزينب تصلي فإذا كسلت أو فترت أمسكت بها، فقال: "حلوه ليصل أحدكم نشاطه فإذا كسل أو فتر قعد".

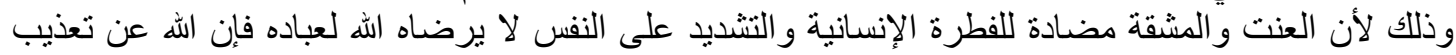
أنفسنا في عبادته لغنى.

$$
\text { قصة أبو إسرائيل رضي الله عنه }
$$

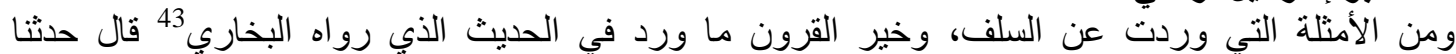

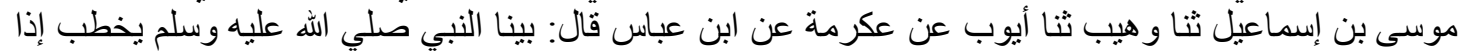

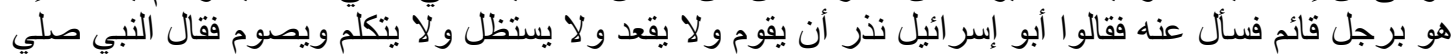

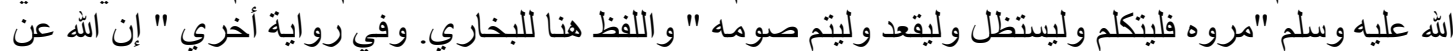

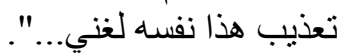
شرع الله عدل بين الغالي فيه و الجافي عنه

$$
\text { * الدين يسر مقال منشور بمجلة التوحيد العدد (12) (ص/12)، السنة (21)، الشيخ محمد علي عبد الرحيم. }
$$




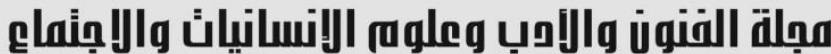

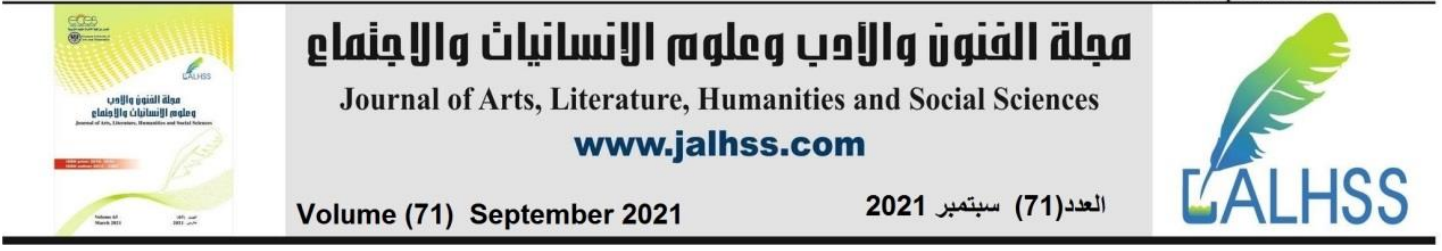

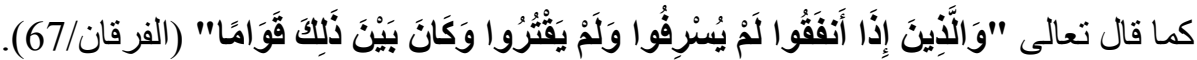

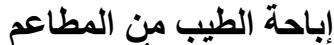

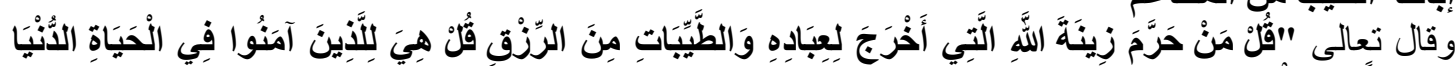

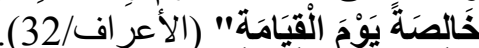

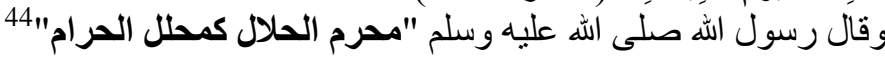

\section{وقال عليه الصلاة والسلام "إن الله يحب أن يري أثر نعمته على عبده في مأكله ومشربه" التخفيف في الصلاة والنهي عن الإطالة}

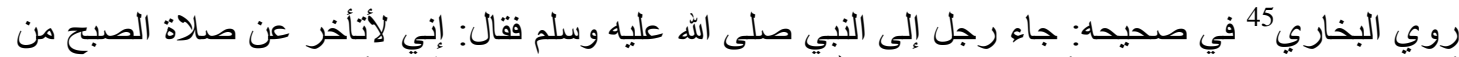

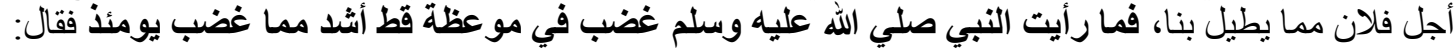

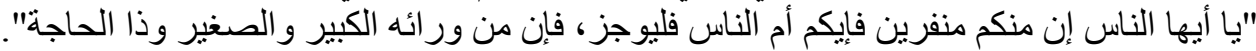

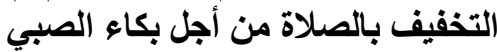
أمه بـه"النبي صلي الله عليه وسلم قال: "إني لأدخل في الني الصلاة أريد إطالتها فأسمع بكاء الصبي فأخفق من شدة وجد و والوجد: بطلق على الحزن، و على الحب أيضا كلاهما سائغ هنا.

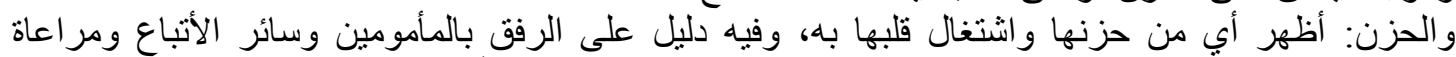

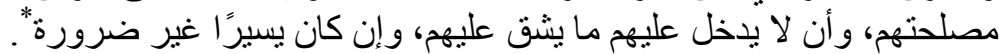
المحور السادس: الوسطية في المعاملات و مكارم الاخلاق

منهج القرآن في مسائل المعاملات

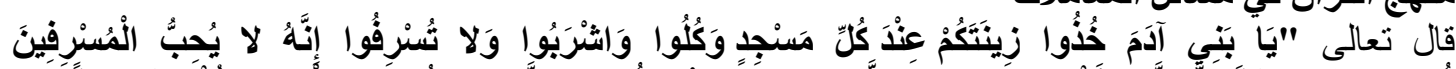

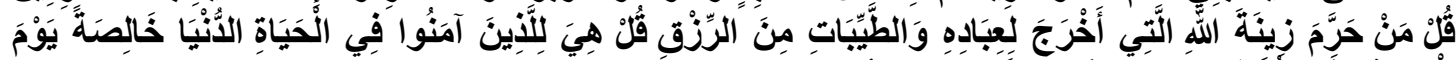

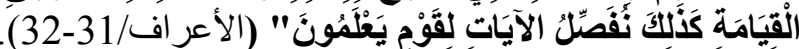

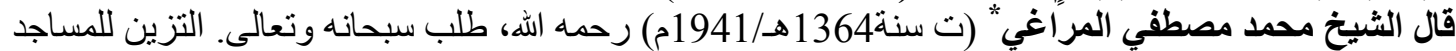

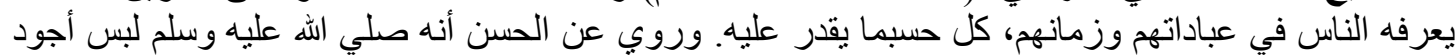

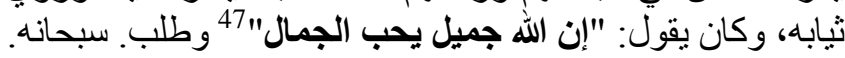

ومن أمور الوسطية:-

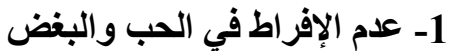

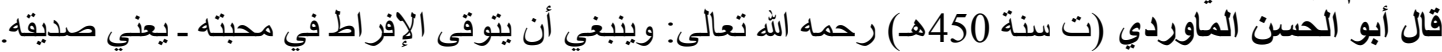

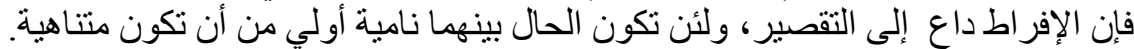

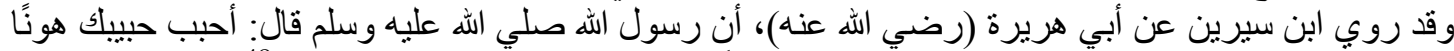

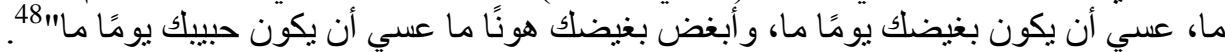

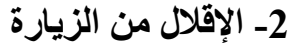

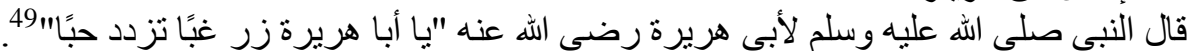

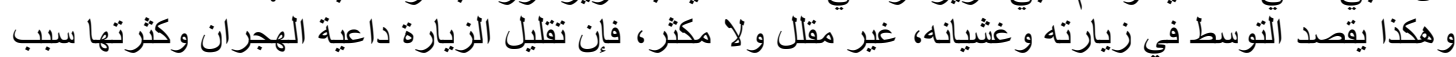

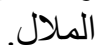

3- والحذر من الإسراف والبخل

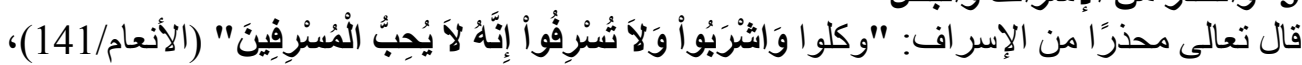

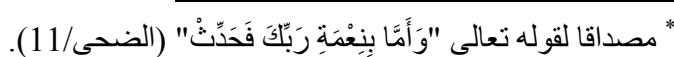

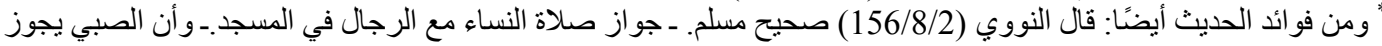

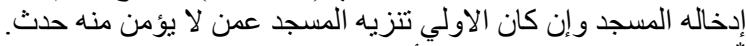

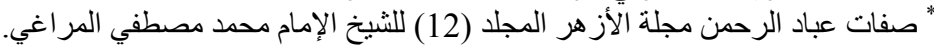




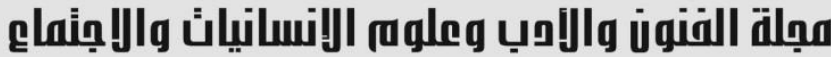

Journal of Arts, Literature, Humanities and Social Sciences

www.jalhss.com

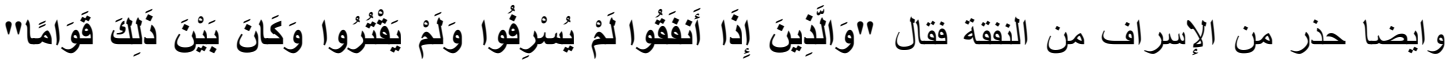
(الفرقان/67)،

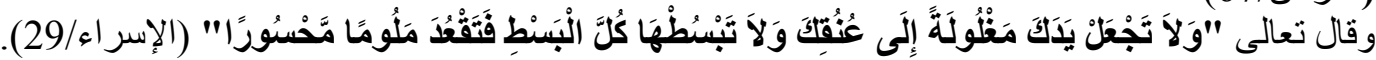
وينبخي على المرء أن يعلم أن الشجاعة: وسط بين الجبن و التهور.

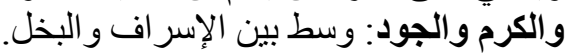
و والمروءة: وسط بين الدناءة والطيش. واللين: وسط بين الضعف و والقيط القسوة. والحياء: وسط بين الوقاحة و الضعة. والطلم: وسط بين الجهل و الفتور ، و البرود. فالقصد. . القصد، وخير الأمور أوساطها.

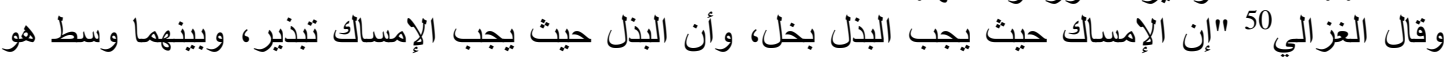

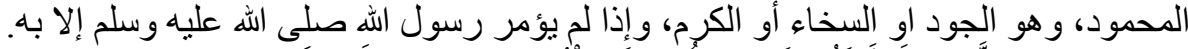

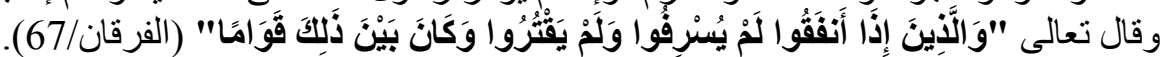

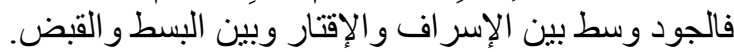

4- أن الله يحب أن بري أثثار نعمته على عباده

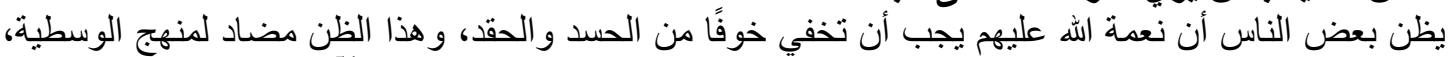

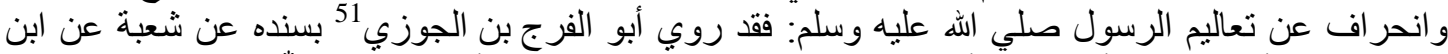

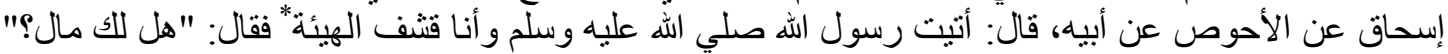

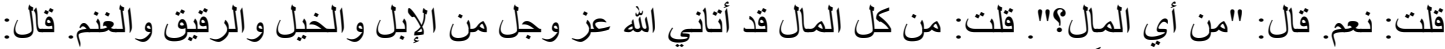

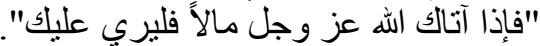

$$
\text { وفي ختام هذا البحث توصلت الى أهم النتائج و التوصيات. }
$$

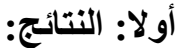

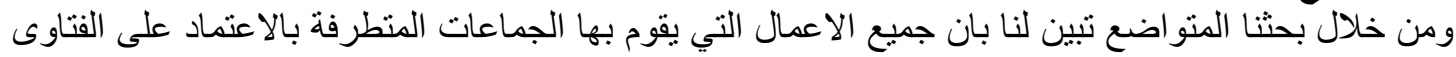

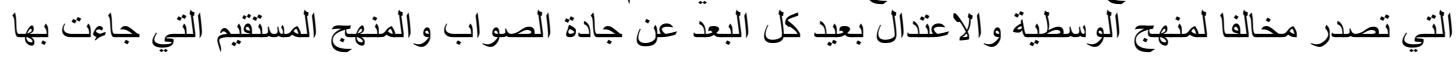
النبي صلى الله عليه وسلم.

$$
\text { ثانيا: التوصيات والمقترحات }
$$

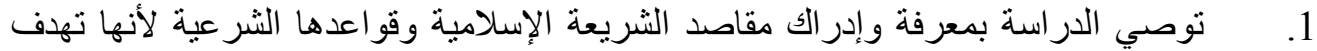

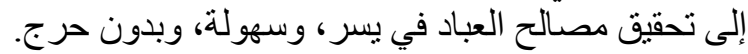

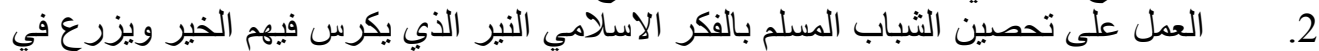

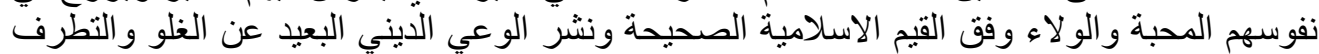

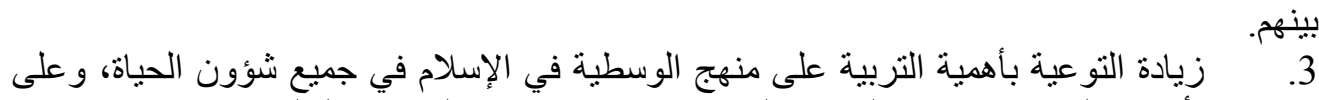
مستوى الأفر اد و الجماعات، فئهي الحصن التربة على الحصين من الانحر افات الفكريةٌ والسلوكية. 


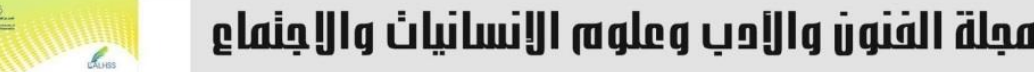

www.jalhss.com

1- الطبري (244-310ه): أبو جعفر، محمد بن جرير بن بزيد بن كثير بن غالب، "جامع البيان في تفسير

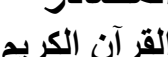
كتب التفسير

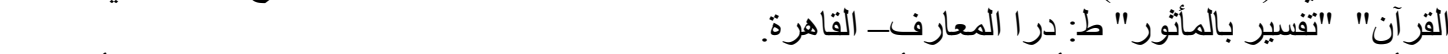

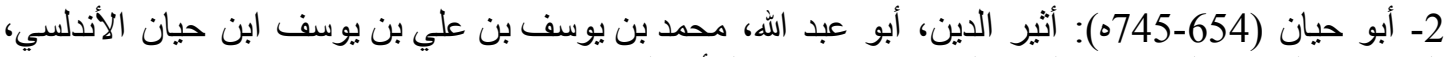

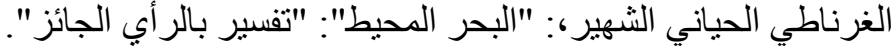

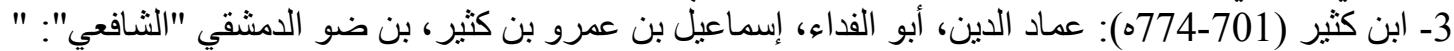

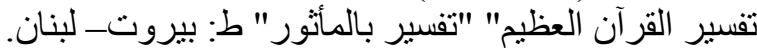
4ـ البقاعي (809-885ه): بر هان الدين: الدين: "تفسير البقاعي".

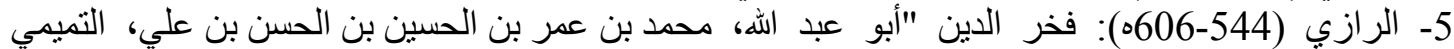

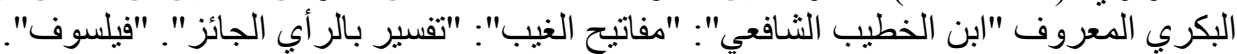

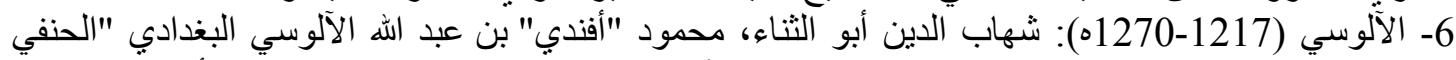

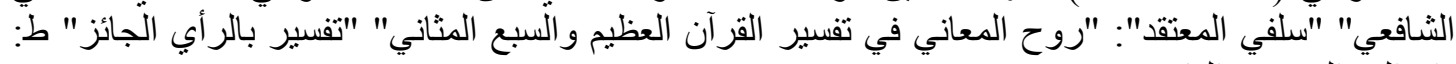

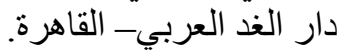
7- قطب (1324-1386ه): سيد قطب: "في ظلال القرآن": "من الوان التفسير الادبيـ الحديث" "أنسعري في

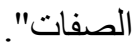
8ـ الدامغاني: "الوجوهو والنظائر لألفاظ الكتاب العزيز"

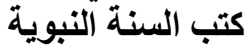

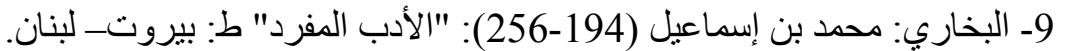

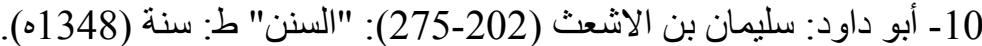

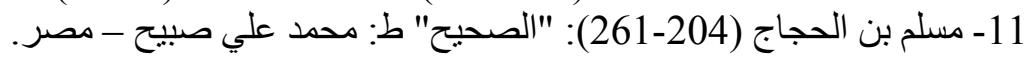

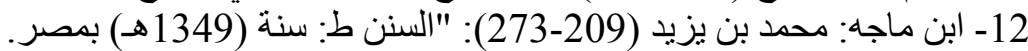

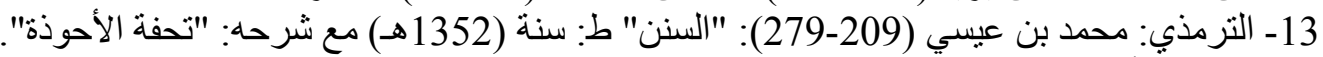

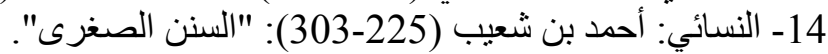

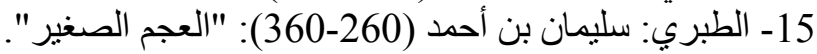

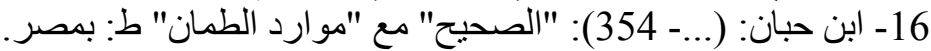

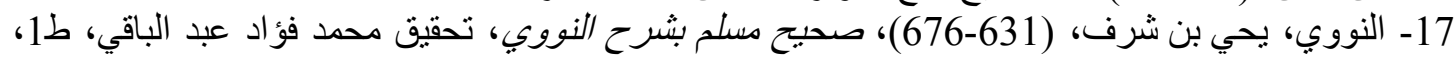

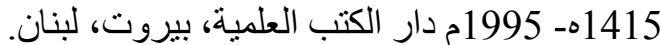

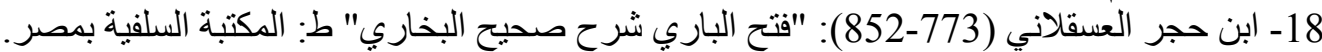

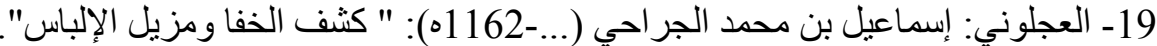

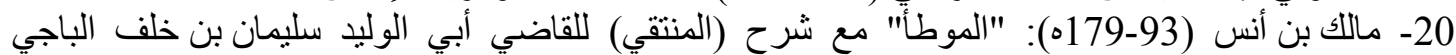

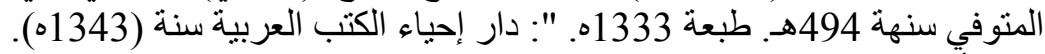

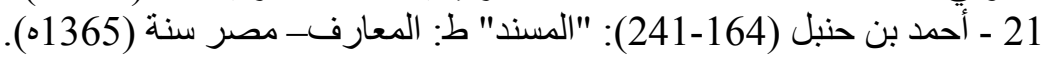

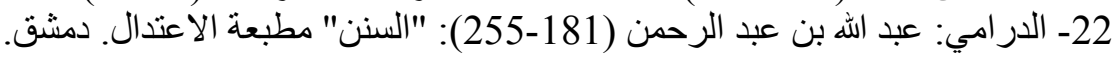

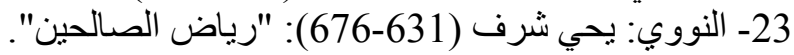

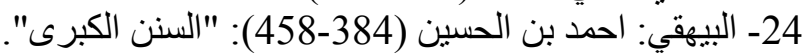

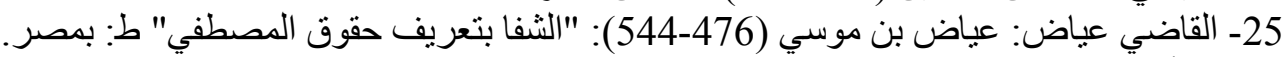

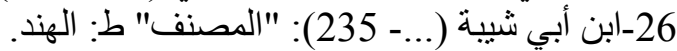
27- البخاري: محمد بن إسماعيل (235): لئيل (256): "الجامع الصحيح" ط: بيروت_ لبنان مع شرحه "فتح الباري". كتب أصنول القبن الققه: 


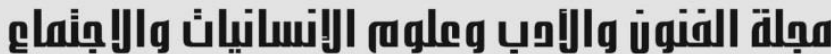

Journal of Arts, Literature, Humanities and Social Sciences

www.jalhss.com

29- الثاطبي: أبو إسحاق إبر اهيم بن موسي اللخمي، (...-790 ): "المو افقات في أصول الأحكام "تعليق: محمد الهد الخضر حسين" ط: المطبعة السلفية بمصر (1341) وبشرح د. دحمد عبد الله دراز ط: مصطفي أحمد (مالكي). بيروت_ لبنان. 30-ابن تيمية: أحمد بن عبد الحليم بن عبد السلام (661-728): "منهاج السنة النبوية".

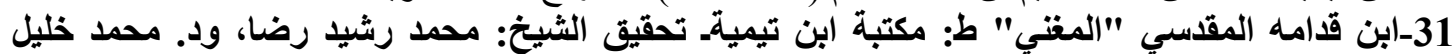

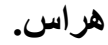
32- الرازي: أبي الحسين أحمد بن فارس بن زكريا (...- 395): "معجم مقاييس اللغة" تحقيق: عبد السلام

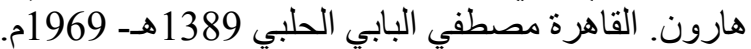

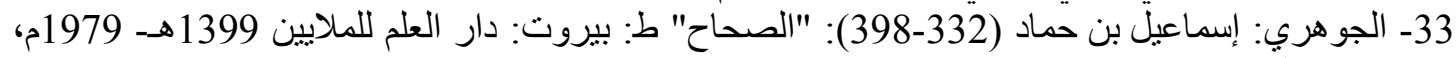
تحقيق: عبد الغفور عطار. 34- الرازي: محمد بن ابي بكر بن عبد القادر (...- 666): "مختار الصحاح" بيروت. دار الكتاب العربي

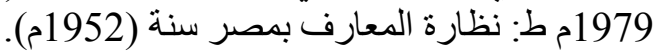
35- ابن منظور: أبو الفضل جمال الدين محمد بن مكرم بن منظور الإفريقي المصري الأنصاري الخزرجي

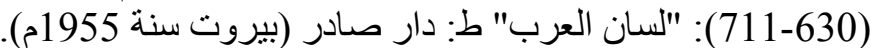
36- الفيروز آبادي: أبو طاهر مجد الدين محمد بن بعقوب (729-816) (1929): "بصائر ذوي التمييز في لطائف الكتاب العزيز" ط: بيروت المكتبة العلمية، بتحقيق: محمد النجار. 37- الفيروز آبادي: محمد بن يعقوب (729-816): "القاموس المحيط" طبعة أولي سنة 1406هـ، بيروت،

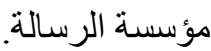
38- مجمع اللغة العربية: "المعجم الوسيط" ط: سنة 1960م.

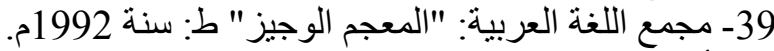

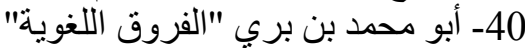
كتب الزهد والمواعظ والآداب

41 القرضاوي: يوسف القرضاوي (معاصر ): "الصحوة الإسلامية بين الجحود و التطرف".

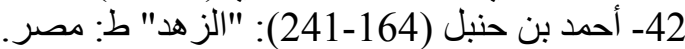

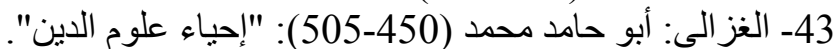
44- ابن الجوزي: أبو الفرج عبد الرحمن (505): "510-597): "تلبيس إبليس" ط: بين" بيروت. المجلات

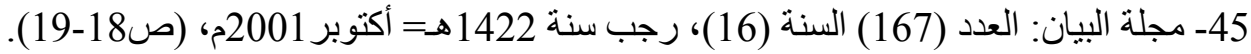

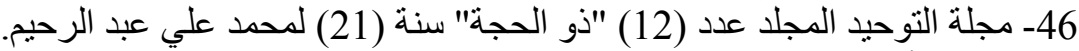
47- مجلة الأز هر المجلد (12)، للإمام محمد مصطفى المر اغي.

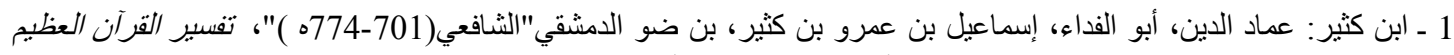

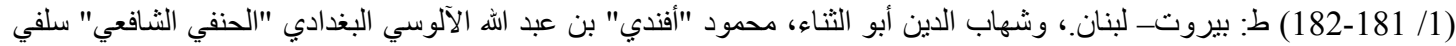

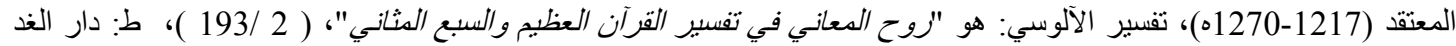
العربي- القاهرة. 2 - أحمد بن فارس بن زكريا (...- 395): "مقابيس اللغة ": تحقيق: عبد السلام هارون، القاهرة مصطفي البابي الحلبي، (108/6)، (1989)،

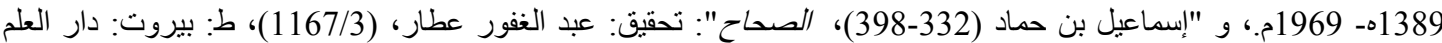

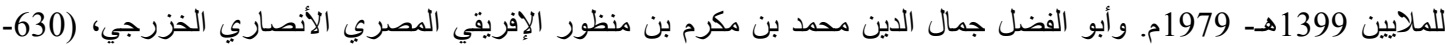

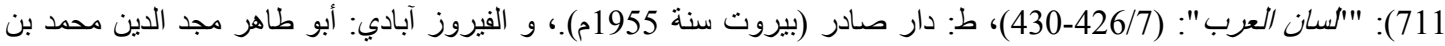

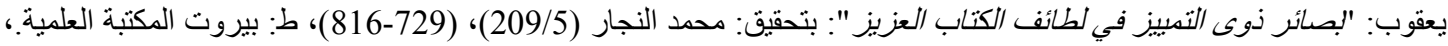

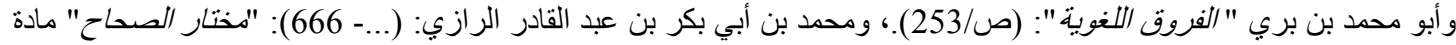

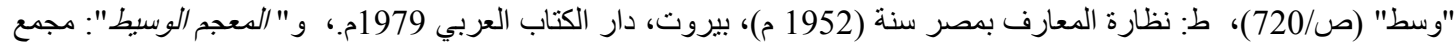




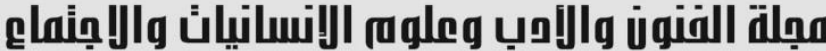

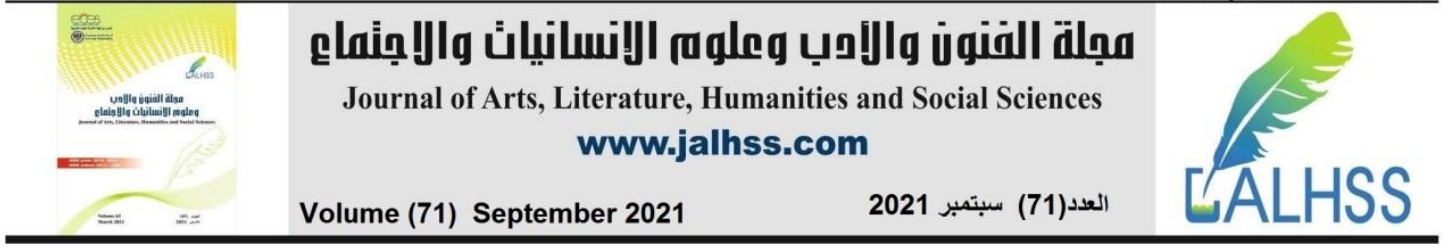

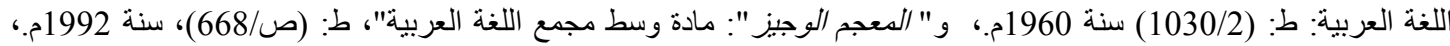

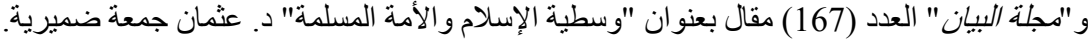

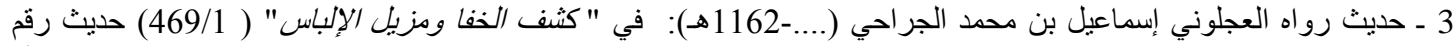

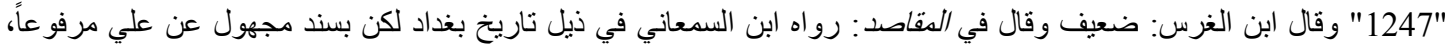

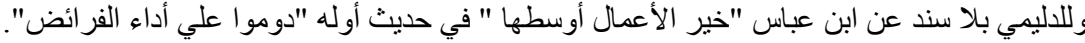

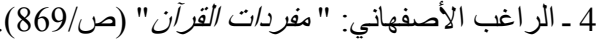

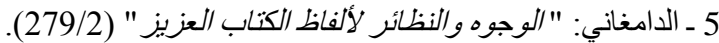

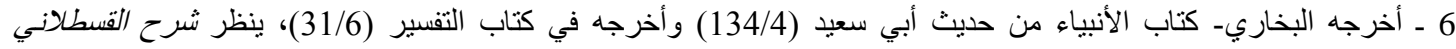

7 ـ برهان الدين البقاعي: "تفسير البقاعي" ، (206/2).

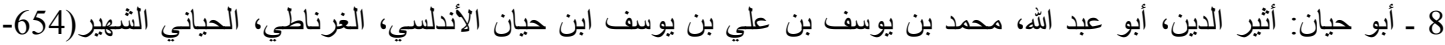

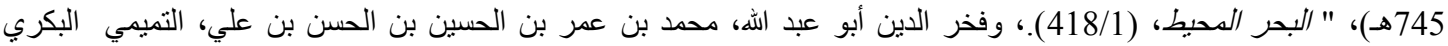

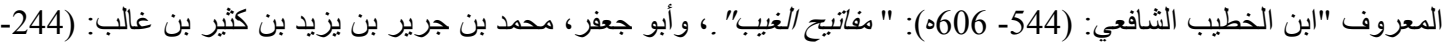

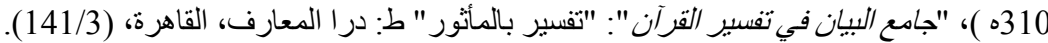

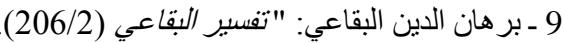

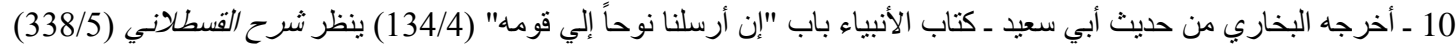

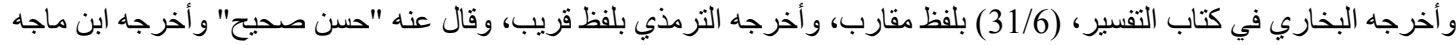

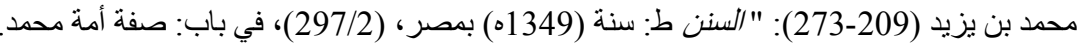

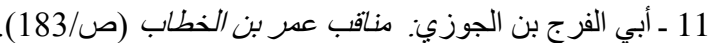
12 ـ ابن منظور الإفريقي: لسان العرب العزب (161/18).

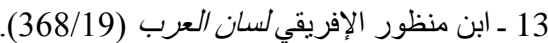
14 - رواه أبو داود: سليمان بن الاشعث (202-275): " السنن" ط: سنة (1348ه).، والترمذي: محمد بن عيسي (209-279):

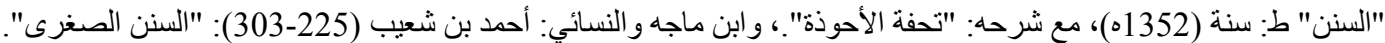

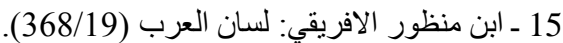

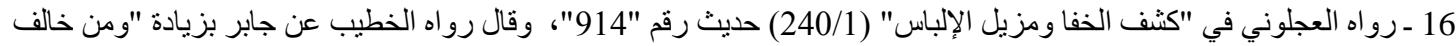

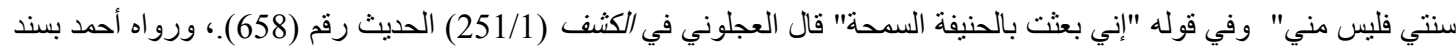

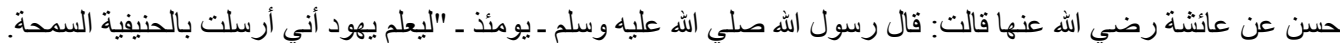

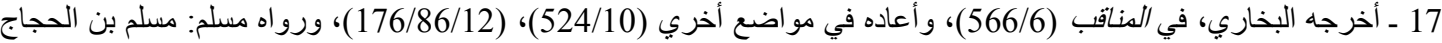

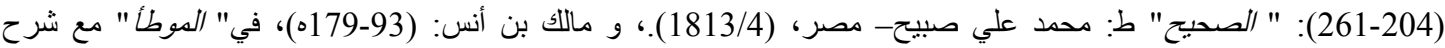

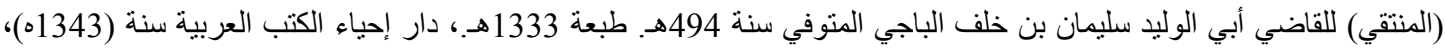

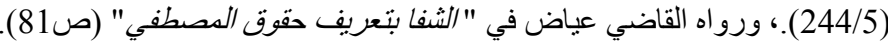

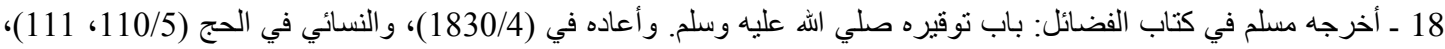

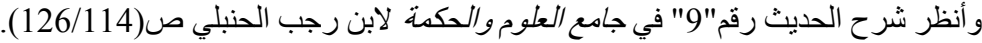

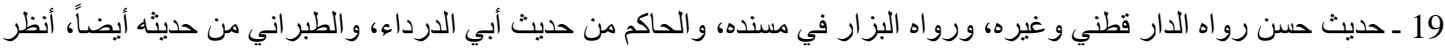

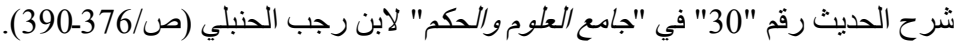

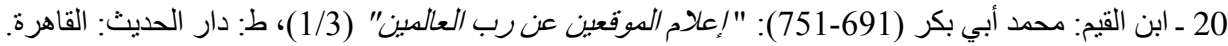

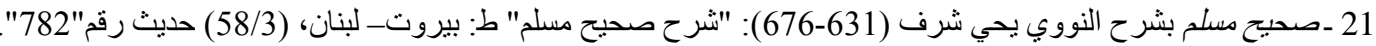

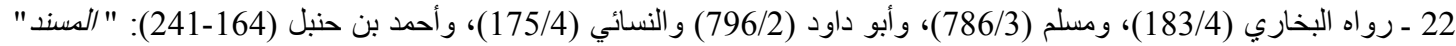

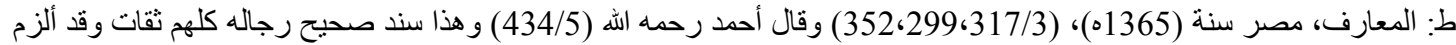

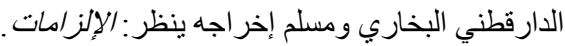

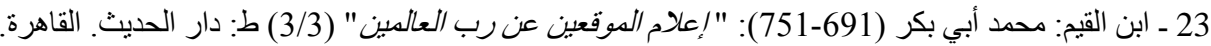

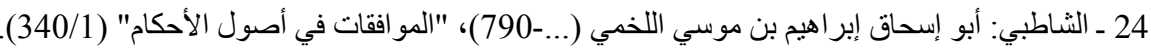

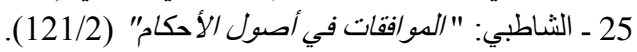
26 - المصدر نفسه (121/2-125)

27 الطبري محمد بن جرير (ت سنة 123 110ه): "جامع البيان في تفسير القرآن"، ( 3 / 142 ـ ).، و مجلة البيان (142/3).

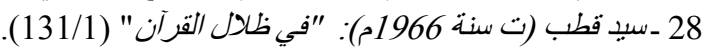
29 - ابن تيمية شيخ الاسلام: (ت سنة 728ه): "منهاج السنة النبوية" (131/1) (173/5). 


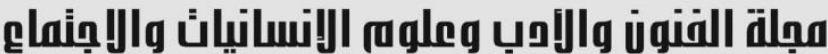

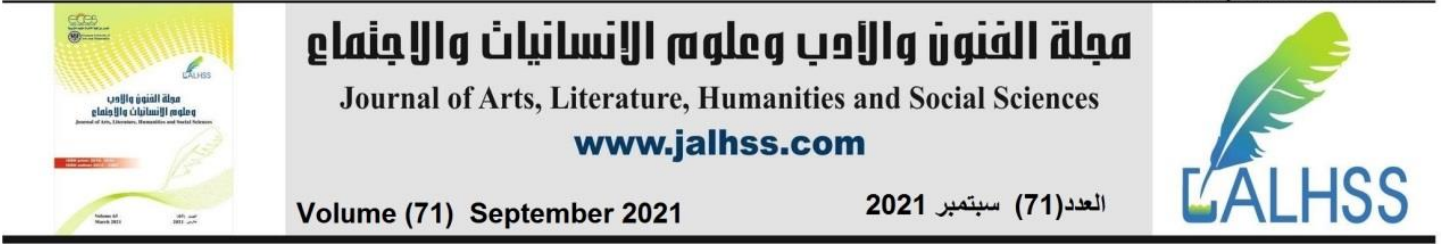

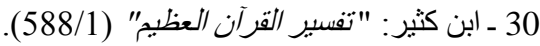
31 - رواه البخاري (378/6) ابنيرة)، وأخرجه الدرامي في الرقاق: عبد الله بن عبد الرحمن (181-255): " السنن" مطبعة الاعتدال، دمشق،

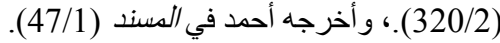

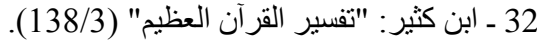
33 - أبي الفضل القاضي عياض بن موسي بن عياض اليحصبي (ت سنة 544 ه): "الثفا بتعريف حقوق سيبنا المصطفي" (ص/33234 ـ صحيح مسلم بشرح النووي (58/3)، حديث رقم (782)، و اللفظ هنا للبخاري ينظر: فتح الباري لابن حجر العسقلاني: باب الاقتصاد في العبادة.

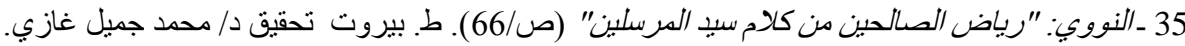

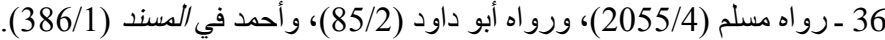
37 ـ مسلم بشرح النووي (190/8) حديث رقم (2670).

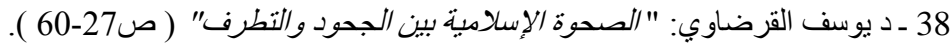

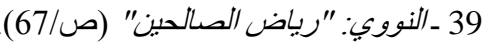

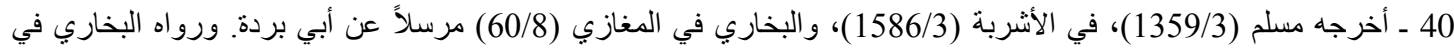

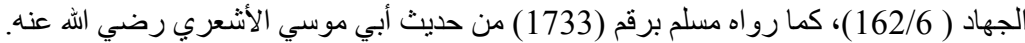

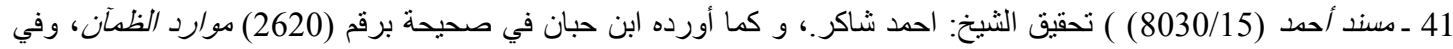

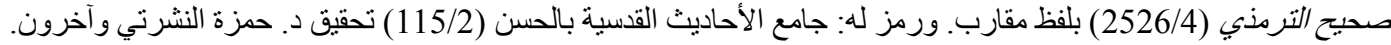

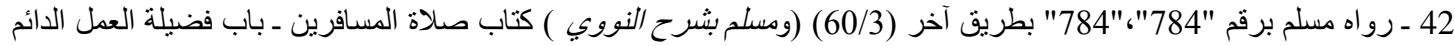

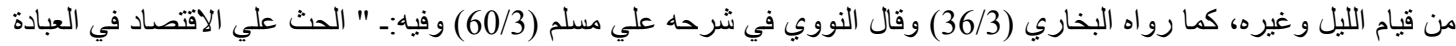

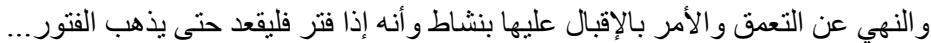

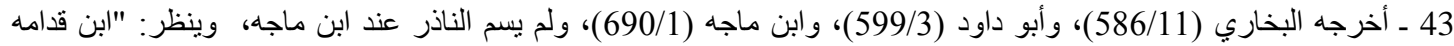
المقدسي" كتابه المغني (5/9) " كتاب النذور "ط" مكتبة ابن تيمية ـ تحقيق الثيخ / محمد رشيد رضا داند/ محمد خليل هر اس. 44 45 ـ الحديث أخرجه البخاري: كتاب الأذان باب من شكا إمامه إذا طول (704). ومسلم: كتاب الصلاة: باب القراءة في العشاء (466)،(182) من حديثه أبي مسعود الأنصاري رئه رضي الله عنه.

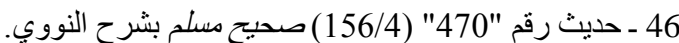

47 - رواه أحمد في مسنده (133/4، 134، 134، 151، 15/4، 241).

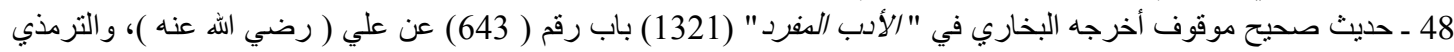

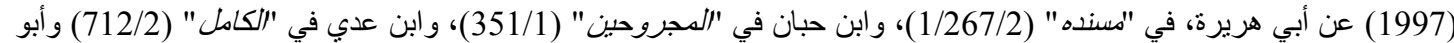

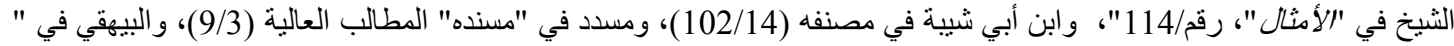
الثعب" (6168-6170) بسند حسن. 49 ـ الحديث رواه البخاري في الأب المفرد، محمد بن إسماعيل (194-256): ط: بيروت- لبنان. وقد صار هذا المنل مضرب

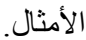

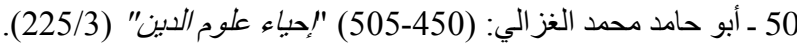

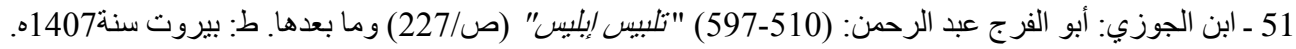

